\title{
Nas malhas da justiça: uma análise dos dados oficiais de indiciados por drogas em Belo Horizonte (2008-2015)
}

Ludmila Mendonça Lopes Ribeiro

Rafael Lacerda Silveira Rocha

Vinícius Assis Couto

\section{Introdução $^{1}$}

Em junho de 2016, o Brasil ganhou um novo Secretário Nacional de Política sobre Drogas (Senad). Em sua primeira entrevista, Osmar Terra afirmou que seu compromisso com a nação brasileira seria a forte repressão ao tráfico de drogas, já que, sem isso, o consumo dessas substâncias ilícitas iria aumentar de forma expressiva ${ }^{2}$. A fala do ministro foi considerada pelos setores mais progressistas de nossa sociedade como extremamente retrógada, dada a discussão em torno da descriminalização do uso de entorpecentes ${ }^{3}$. Porém, os operadores do sistema de justiça criminal se sentiram representados no discurso do novo Senad, dado que a repressão tem sido o padrão de operação dessas instituições (Campos, 2015).

Os estudos sobre administração da justiça nos crimes que envolvem fabricação, comércio e uso de drogas identificam como ponto de inflexão da política de drogas brasileira a promulgação da Lei 11.343, em 23 de agosto de 2006. Àquela época, a preocupação dos legisladores era dar um tratamento diferenciado entre os dependentes de substâncias químicas ilegais e os responsáveis por sua sintetização ou distribuição. Essa lei não estabeleceu, contudo, critérios suficientemente evidentes de distinção entre usuários e traficantes ${ }^{4}$, ficando a cargo dos funcionários das organizações policiais e do

\footnotetext{
1 Trabalho realizado com o apoio financeiro do CNPq, processo 307371/2015-8. Uma primeira versão deste artigo foi apresentada no $10^{\circ}$ Encontro da Associação Brasileira de Ciência Política, realizado em Belo Horizonte entre os dias 30 de agosto a 2 de setembro de 2016. Os autores agradecem os comentários de Luis Flávio Sapori, que foi debatedor da sessão, pelas reflexões que contribuíram para a melhoria do argumento. Agradecem ainda aos alunos Pedro Machado e Lívia Lages, ambos do Programa de PósGraduação em Sociologia da Universidade Federal de Minas Gerais, que usaram suas experiências com a prática jurídica para a revisão das minúcias legais deste artigo. Por fim, agradecem aos pareceristas anônimos da revista Opinião Pública, cujas sugestões foram incorporadas ao texto final.

2 Nesse sentido, ver: <http://oglobo.globo.com/sociedade/tem-que-ter-punicao-senao-usuario-vaiconsumir-mais-drogas-diz-ministro-19454345>. Acesso em: 28 jun. 2016.

3 Nesse sentido, ver: <https://igarape.org.br/en/dez-motivos-para-mudar-a-forma-como-o-pais-lida-comas-drogas/>. Acesso em: 28 jun. 2016.

${ }^{4}$ Art. 28. Quem adquirir, guardar, tiver em depósito, transportar ou trouxer consigo, para consumo pessoal, drogas sem autorização ou em desacordo com determinação legal ou regulamentar será submetido às seguintes penas: I - advertência sobre os efeitos das drogas; II - prestação de serviços à comunidade; III -
} 
sistema de justiça criminal a tarefa de distingui-los, o que é feito a partir de características eminentemente subjetivas ${ }^{5}$.

A Nota Técnica de agosto de 2015 do Instituto Igarapé 6 procura problematizar essa indefinição ao sublinhar que, dos oito critérios legais de distinção entre o porte para uso próprio e o tráfico de drogas (a quantidade e a natureza da substância apreendida; o local e as condições da ação; as circunstâncias sociais e pessoais; a conduta; os antecedentes do agente), somente dois são objetivos (a quantidade e a natureza da substância apreendida), sendo que a quantidade, apesar de objetiva, se tornou subjetiva, dada a ausência de consenso sobre o que é muita ou pouca droga (Lemgruber e Fernandes, 2015). Por isso, entendemos que "uma das incongruências desta lei é a ausência da indicação de uma quantidade a partir da qual se configura tráfico", cabendo aos operadores do direito "avaliar se determinado indivíduo é usuário ou traficante, o que não garante nenhuma imparcialidade no processo" (Helpes, 2014, p. 3). Em suma, a quantidade de entorpecente não é um critério objetivo de distinção de "posse para uso próprio" e "tráfico ou condutas afins".

Em razão dessa ausência de delimitação, com base na quantidade de drogas, entre quem é usuário e quem é traficante, desde a publicação da Nova Lei de Drogas, inúmeros cientistas sociais têm procurado compreender como o sistema de justiça criminal administra esses delitos e quais são os efeitos que a guerra às drogas produz em nossa sociedade (Campos, 2015). Parte desses estudos indica que os operadores do direito entendem que o espraiamento da criminalidade, sobretudo a violenta, é resultado da expansão do comércio de drogas ilegais (Machado e Porto, 2015). Por isso, é preciso reprimir com maior vigor os sujeitos identificados como traficantes, sendo essa a razão para o crescimento de mais de $60 \%$ da população prisional brasileira na última década (Azevedo e Cifali, 2015), com destaque para os estados de São Paulo e Minas Gerais, que aumentaram substantivamente a quantidade de indivíduos encarcerados por tráfico de drogas (Lima, Sinhoretto e Bueno, 2015).

Partindo desse cenário, a proposta deste artigo é compreender como as Varas Criminais de Tóxico, instituídas na cidade de Belo Horizonte no ano de 2008, administram os delitos previstos na Lei de Drogas. Estamos especialmente interessados em verificar quais são os delitos com maior participação percentual no total de processos penais encerrados na capital mineira entre janeiro de 2008 e setembro de 2015. Em seguida,

medida educativa de comparecimento a programa ou curso educativo. Art. 33. Importar, exportar, remeter, preparar, produzir, fabricar, adquirir, vender, expor à venda, oferecer, ter em depósito, transportar, trazer consigo, guardar, prescrever, ministrar, entregar a consumo ou fornecer drogas, ainda que gratuitamente, sem autorização ou em desacordo com determinação legal ou regulamentar: Pena - reclusão de 5 (cinco) a 15 (quinze) anos e pagamento de 500 (quinhentos) a 1.500 (mil e quinhentos) dias-multa.

5 É bom destacar que a dificuldade de diferenciação entre traficantes e usuários existia na legislação anterior, como demonstra Mingardi (1992) em estudo sobre funcionamento da Polícia Civil. Ocorre que, naquele cenário, a principal consequência do enquadramento em uma categoria em detrimento da outra era o tempo de pena. Como se argumentará, na Nova Lei de Drogas o problema é mais complexo porque o usuário é despenalizado e o traficante recebe uma pena de privação de liberdade maior que a existente na legislação anterior.

$6 \quad$ Disponível em: <https://igarape.org.br/wp-content/uploads/2015/08/Nota-t\%C3\%A9cnicaIgarap\%C3\%A9-_08-2015.pdf>. Acesso em: 28 jun. 2016. 
enfocamos o crime de tráfico de drogas, procurando compreender como ele é administrado em termos de mecanismos de incriminação (se por prisão em flagrante ou inquérito policial) e tempo de tramitação do processo penal. Infelizmente, as questões sobre o desfecho processual (condenação ou absolvição) ficaram prejudicadas em razão da ausência dessa informação na base de dados cedida para esse estudo.

As perguntas que este artigo pretende responder são: qual é a participação percentual do delito de tráfico de drogas no total de procedimentos examinados pelo Tribunal de Justiça de Minas Gerais (TJMG)? Quais são os fatores determinantes do tempo de processamento do delito de tráfico de drogas na justiça de Minas Gerais? No caso do tráfico de drogas, a forma de operação do TJMG pode ser qualificada de "justiça em linha de montagem" (Sapori, 1995)?

Para responder a essas perguntas, foram utilizados os dados de movimentação processual cedidos pelo Tribunal de Justiça de Minas Gerais, que dizem respeito a todos os procedimentos completos, ou seja, casos encerrados entre janeiro de 2008 e setembro de 2015. Esses dados possuem uma série de limitações, mas, por serem oficiais, permitem certa compreensão de como o Estado se posiciona frente a esses delitos.

\section{Revisão dos estudos sobre aplicação da Nova Lei de Drogas}

Anterior à chamada Nova Lei de Drogas vigorava a Lei 6.368/76, afinada com o modelo político-criminal de combate ao tráfico de drogas estabelecido ao longo de uma série de tratados e convenções internacionais ${ }^{8}$. A Lei $6.368 / 76$ previa a diferenciação penal entre usuário e traficante, imputando aos primeiros penas de detenção de seis meses a dois anos, além de multa, e, aos últimos, pena de reclusão de três a 15 anos, acrescida de multa. A antiga lei também determinava a possibilidade de internação hospitalar obrigatória em casos nos quais "o quadro clínico do dependente ou a natureza de suas manifestações psicopatológicas assim o exigirem" (art. 10), que, junto com a detenção prevista para usuários, evidenciam o estágio incipiente da diferenciação entre as sanções penais e as abordagens médicas (Campos, 2015).

Desde os anos 1980, verifica-se o interesse de cientistas sociais no sentido de entender como as organizações do sistema de justiça criminal aplicavam essas normativas jurídicas, na proposta de apreender quais eram os elementos que permitiam aos agentes estatais acusarem alguém do envolvimento com substâncias entorpecentes e como esse

\footnotetext{
7 Os estudos revisados nesta seção não são referentes a Belo Horizonte, onde os trabalhos sobre tráfico de drogas estão mais relacionados ao uso da morte violenta como mecanismo de administração de conflitos do que à forma como traficantes e usuários são diferenciados. Além disso, inexistem, na capital mineira, estudos sobre o tratamento dado pelo sistema de justiça criminal ao indivíduo enquadrado pela polícia como traficante. Para um melhor entendimento dos efeitos do tráfico na dinâmica homicida da cidade, ver Beato e Zilli (2012).

8 Em especial a Convenção Única sobre Entorpecentes de 1961 e a Convenção sobre Substâncias Psicotrópicas de 1971. Uma discussão detalhada sobre o conteúdo desses encontros foi feita por Boiteux (2009).
} 
enquadramento era construído para diferenciar usuários e traficantes, já que muitas vezes essas fronteiras não estavam explícitas.

Um dos pioneiros nessa área foi Velho, que procurou descortinar como "os tóxicos são utilizados e reprimidos de forma bastante diferenciada, basicamente, em função de classe social, estrato ou grupo de status a que pertença o consumidor" (1998, p. 204). Dependendo do tipo de droga e de quem a utilizava, a substância entorpecente servia para marcar "um estilo de vida sofisticado" em oposição ao drogado, categoria aplicada aos jovens de periferia como forma de transformá-los em desviantes e, dessa maneira, matéria-prima para o sistema de justiça criminal. Mesmo porque, na legislação anterior, existia a internação compulsória aplicada aos drogados. Assim, a diferença entre usuários e traficantes não dizia respeito à natureza da conduta desviante, mas à classe social de quem praticou a ação delituosa que, por sua vez, aumentava ou diminuía a chance de o indivíduo interagir com a polícia, principal responsável por enquadrar o indivíduo dentro de uma norma penal, transformando-o em um criminoso.

Ao deslocar a análise da lei para a forma como a interação leva ao enquadramento de um indivíduo dentro da lei, Velho desvela como "não existem desviantes em si mesmos, mas sim uma relação entre atores (indivíduos, grupos) que acusam outros atores de estarem consciente ou inconscientemente quebrando, com seu comportamento, limites e valores de uma determinada situação sociocultural" (1974, p. 23). Em um contexto como esse, "o tóxico não apenas tem significados diferentes em função do grupo que o utiliza, como a sua utilização pode ser interpretada por não consumidores, acusadores potenciais e autoridades de maneira diferente, provocando reações particulares" (Velho, 1998, p. 205). Assim, a acusação de drogado carregava em si uma repressão moral maior do que o apontamento de uma ruptura com uma normativa jurídico penal. Ser drogado era uma condenação (penal e moral) de um estilo de vida, do pertencimento a um dado grupo social, se constituindo em uma espécie de "acusação moral e médica que assume explicitamente uma dimensão política, sendo, portanto, também uma acusação totalizadora" (Velho, 1978, p. 63).

Enquanto Velho aborda a categoria de acusação de alguém de drogado como uma estratégia de exercício de poder, já que apenas determinados segmentos são enquadrados como usuários e traficantes de drogas, Zaluar sublinha a importância de se entender as diferenciações que ocorrem entre acusadores e acusados dentro das classes populares. Em seu trabalho na cidade maravilhosa, a autora retrata como, na década de 1980, na interação cotidiana estabelecida em ambientes de favela, os sujeitos se diferenciavam entre trabalhadores, que são disciplinados pelas fábricas e trabalham para sobreviver; malandros, que se recusam ao trabalho, mas são queridos na comunidade, posto que usam da palavra para o convencimento de algo ilegal ou imoral; e bandidos, vistos dentro e fora das favelas como "marginais, imorais, escória, lixo da sociedade" (Zaluar, 1985, p. 133), uma vez que, além de se recusarem ao trabalho, se utilizam da arma de fogo para impor a sua vontade. 
Essa tríade se transforma em díade a partir do final da década de 1980, quando o bandido se subsume na figura do traficante que reside na favela, o qual é transformado em um dos principais alvos das políticas repressivas estatais. É nesse momento que o traficante se transforma em um símbolo de ameaça, na encarnação do bandido, percebido, tanto no plano moral como no da segurança, como um elemento que precisa ser atacado e que, em última instância, pode ser morto (Misse, 2010). É nesse contexto que os residentes de favela se consolidam em inimigos, cabendo à polícia a vigilância das "classes perigosas" como forma de garantia da segurança de toda a sociedade (Paixão, 1982), o que explicaria a homogeneidade social tanto de drogados como de traficantes conhecidos ${ }^{9}$ pelo sistema de justiça criminal (Velho, 1998).

É nesse plano mais geral, que aborda como as leis de drogas operam historicamente como um mecanismo hierárquico de diferenciação de classes sociais, transformando os moradores de favela em traficantes e drogados e negando a existência de comerciantes e usuários dessas substâncias em outras áreas das grandes cidades, que devemos compreender as mudanças - legais e administrativas - propostas no Congresso Nacional e consolidadas na Nova Lei de Drogas.

Ao final da década de 1990, em consonância com o início do deslocamento das organizações internacionais de uma postura de "guerra às drogas" para o paradigma da "redução de danos", houve no Congresso Nacional uma tentativa de reforma da Lei de Drogas. Esse movimento deu origem à Lei 10.409/02, que previa medidas de redução de pena para usuários. Essa proposta teve parte de seus artigos vetada pela Presidência da República, o que diminuiu enormemente o alcance das mudanças, dado que todos os potenciais critérios de diferenciação entre usuários e traficantes foram rechaçados. Entendendo que, após os vetos, a Nova Lei de Drogas alteraria pouco as políticas executadas até então, do ponto de vista do tratamento diferenciado que deveria ser concedido a traficantes e usuários, no mesmo ano, o Poder Executivo encaminhou o novo Projeto de Lei no 6.108/02, que tramitou dois anos na Câmara dos Deputados, sendo aprovado em 2004. Tal projeto, após alterações, deu origem a Lei no 11.343, sancionada em 23/8/2006, e que começou a vigorar imediatamente.

De acordo com Boiteux (2010), a Nova Lei de Drogas trouxe avanços, muitas vezes colocados em segundo plano ante a despenalização da posse para uso próprio (presente no artigo 28), tais como: a equiparação do usuário com o chamado grower, palavra que identifica quem faz o plantio para consumo próprio (art. $28, \S 1^{\circ}$ ) e a redução da pena para

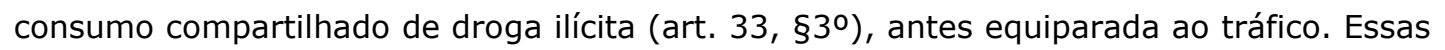
medidas refletem, ao menos como proposta, uma redução do controle penal sobre o usuário de drogas, enquanto reforçam o reconhecimento de princípios da autonomia e responsabilidade individual em relação ao uso de drogas ilícitas.

\footnotetext{
9 Para Velho (1998) também existem traficantes e usuários de drogas entre as classes sociais mais altas, porém, estes não são conhecidos pelo sistema de justiça criminal, já que a polícia não enxerga tais indivíduos como desviantes e, por isso, não centra a sua vigilância sobre eles. Com isso, tais sujeitos não são autuados em flagrante pela polícia, nem denunciados como traficantes pelo Ministério Público ou condenados pelo juiz, sendo essa a razão pela qual eles não estão representados dentro das prisões.
} 
Todavia, se a Lei 11.343/06 apresenta uma proposta de redução do controle penal no uso de drogas, o mesmo não pode ser dito em relação ao tráfico. Em contrapartida a uma maior leniência ao usuário, uma das principais mudanças foi o endurecimento da pena ao considerado traficante. A pena mínima por tráfico de drogas passou de três para cinco anos de prisão. Também como medida de endurecimento, a nova lei, em seu artigo 44, instaura a inafiançabilidade do tráfico de drogas, assim como a proibição da concessão de sursis, graça, indulto, anistia e liberdade provisória ${ }^{10}$, além de uma série de proibições à conversão da pena privativa de liberdade em restritiva de direitos.

Segundo Boiteux (2006), a posse de drogas ilícitas para uso próprio já tinha sido despenalizada, na prática, desde a Lei 6.416/77, com o sursis (que dispensa o cumprimento da pena no todo ou em parte) e, posteriormente, com a Lei 9.099/95, que estabeleceu a suspensão condicional do processo, quando o Ministério Público oferece determinadas condições ao acusado para que o processo não siga adiante. Se essas condições forem cumpridas, o indivíduo é liberado sem qualquer tipo de registro em sua folha de antecedentes criminais, pois se entende que o processo penal propriamente dito não chegou a se configurar. Mesmo que a despenalização do usuário seja um avanço simbólico, o aumento da pena mínima por tráfico de drogas representou uma mudança concreta no padrão de operação das agências do sistema de justiça criminal, o que aumentou o tempo de encarceramento dos presos por esse crime e, por conseguinte, resultou em um inchaço sem precedentes do sistema prisional (Azevedo e Cifali, 2015).

Esses dois movimentos simultâneos - despenalização do uso e aumento da punição para o tráfico de drogas - compõem o cerne da chamada Nova Lei de Drogas. A partir da Lei $11.343 / 06$, a distância que separava as figuras do usuário e do traficante na prática jurídica foi largamente estendida, o que engendrou diferentes processos sociais, destinados a ressaltar a hierarquia social entre traficantes e usuários, conhecidos e desconhecidos pelo sistema de justiça criminal, nos termos de Velho (1998).

Campos (2015) escrutinou os pareceres de deputados e senadores à época da elaboração e votação do projeto da Nova Lei de Drogas, demonstrando como o usuário é representado, nesse debate, a partir de uma série de discursos da esfera da saúde, enquanto o traficante é focalizado pelas ações criminalizantes e punitivistas. O traficante passa a ser apresentado como o principal inimigo da sociedade, a quem o sistema de justiça criminal deve reprimir com vigor, o que significa prendê-lo provisoriamente, processá-lo rapidamente e condená-lo a uma pena privativa de liberdade substantiva. A diferenciação entre usuário e traficante, com consequências legais tão distintas, é agravada pela inexistência de uma definição concreta e explícita na Lei de Drogas sobre as circunstâncias em que deve ocorrer o enquadramento em cada uma dessas duas categorias.

Embora inicialmente houvesse uma preocupação em definir um limite objetivo entre a quantidade de drogas para uso próprio e a quantidade a partir da qual se

\footnotetext{
10 No habeas-corpus 104339 de 2012, de relatoria do ministro Gilmar Mendes, o STF passou a entender que essa vedação à liberdade provisória do artigo 44 é inconstitucional.
} 
configuraria prática de tráfico (esboçada nos PL 7134/2002 e PLS 115/2002), a versão final da lei não estabeleceu nenhum quantitativo específico de drogas para diferenciação entre usuários e traficantes. A definição de quem são os usuários, indivíduos "doentes" e focos de ações médicas e sociais, e os traficantes, considerados ameaça à segurança pública e alvo de penas severas, depende da percepção e do entendimento dos atores do sistema de justiça criminal (Boiteux et al., 2009). Sem uma definição do que configura uso e tráfico de drogas no tipo penal, a distinção operada cotidianamente pelos atores do sistema de justiça criminal tem como elemento central as características e trajetórias dos indivíduos denunciados. Não é que antes isso não acontecesse, como demonstram os estudos de Velho (1998) e Mingardi (1992, mas na legislação anterior a fronteira entre usuário e traficante era mais evidente, além de as consequências (prisão, em especial) serem semelhantes, o que não existe mais. Além disso, com a Nova Lei, há um deslocamento do critério de enquadramento no tipo penal do ato (o que ele faz) para o sujeito (quem faz). Isso ocorre porque o perfil de quem foi pego com a droga se torna um elemento determinante na definição de sua conduta como usuário ou traficante. Basta analisar o artigo 28, §2으, que estabelece os elementos a serem analisados pelo juiz para essa operacionalização:

Para determinar se a droga se destina a consumo pessoal, o juiz atenderá à natureza e à quantidade da substância apreendida, ao local e às condições em que se desenvolveu a ação, às circunstâncias sociais e pessoais, bem como à conduta e aos antecedentes do agente (grifos nossos).

Ao entrevistarem juízes e promotores do Distrito Federal no ano seguinte à aprovação da Nova Lei de Drogas, Santoucy, Conceição e Sudbrack (2010) identificaram os padrões difusos utilizados pelos operadores de justiça para a classificação de um suspeito como usuário ou traficante. Critérios mais palpáveis foram citados, como o fato de a droga estar fracionada em diversas unidades (o que pode indicar seu acondicionamento visando à venda). Porém, em consonância com a literatura sociológica sobre o trabalho policial (Paixão, 1982), as características do acusado, como local de moradia e/ou de apreensão, bem como a existência ou não de antecedentes criminais, também eram determinantes para o enquadramento do sujeito dentro dos dois tipos penais. Por isso, parte dos entrevistados ressaltou o caráter pessoal das decisões, sem critérios abrangentes e que, muitas vezes, dependem de certa sensibilidade, pois, como afirmou um dos promotores entrevistados, pela "experiência ali, já sabe mais ou menos como é... geralmente pela situação da pessoa, sente quando já é usuário" (Santoucy, Conceição e Sudbrack, 2010, p. 181).

Nessa mesma direção, o estudo de Campos (2015) em São Paulo concluiu que um indivíduo analfabeto ou com ensino fundamental tem 3,6 vezes mais chances de ser incriminado por tráfico de drogas do que alguém com ensino superior. Também existem desproporções quando o foco é o sexo: as mulheres têm chances 2,3 vezes mais elevadas de serem incriminadas por tráfico do que homens. Para além das características 
individuais, o autor encontrou um aumento nas probabilidades de alguém ser preso na capital paulista por tráfico de drogas após a Lei 11.343/06 entrar em vigor. Comparando o ano de 2009 com o de 2004, quando todas as características do crime e do acusado são levadas em consideração, as chances de uma pessoa ser incriminada por tráfico em vez de uso de drogas aumentam em quatro vezes após a Nova Lei de Drogas, o que pode indicar uma resistência dos operadores do sistema de justiça criminal em qualificar determinados sujeitos como usuários, enquadramento que significaria uma enorme redução de sanções.

Um último ponto de importância na aplicação da Lei 11.343/06 é o instrumento da prisão em flagrante e seus efeitos no decorrer do processo. Os crimes previstos na Lei de Drogas se configuram, em grande parte, a partir do flagrante policial, isto é, do momento em que um agente da lei identifica e apreende um indivíduo porque ele está usando, fabricando ou distribuindo drogas. Proporcionalmente, no agregado dos registros enquadrados na Lei de Drogas nas polícias e na justiça, mais raras são as situações em que os policiais conseguem descortinar um esquema de produção, uso ou tráfico (Jesus et al., 2011). Em regra, os flagrantes são de indivíduos com pouca quantidade de drogas e sob a suspeição de que essas substâncias não seriam para uso próprio, dado que são sujeitos de baixa renda e escolaridade e residentes em áreas de favela, que precisam do dinheiro da venda dessa substância para sobreviverem. Então, populações mais vigiadas (isto é, que possuem o perfil de elemento suspeito) ${ }^{11}$ terminariam mais registradas por tráfico de drogas, dada a maior probabilidade de flagrante nessa situação (Lemgruber e Fernandes, 2015).

O flagrante, geralmente, significa a prisão dos envolvidos até a sentença final, dado o entendimento de que a soltura desse "criminoso" implicará o aumento do mercado de drogas (Jesus et al., 2011). Além disso, a pesquisa sociológica sobre administração da justiça aponta para a redução expressiva do tempo de processamento quando da existência do flagrante, já que este simplifica (e reduz) a coleta de provas e diminui os limites dos prazos legais devido à prioridade para julgamento do réu preso (Vargas, 2014). No presente artigo, procuramos entender como a prisão em flagrante afeta o tempo dos processos, transformando a justiça no âmbito da Lei de Drogas em uma linha de montagem com pouca ou nenhuma preocupação em relação a quem está sendo julgado, ou ainda, qual foi a transgressão praticada: se uso ou tráfico de drogas.

\section{Os registros administrativos como fonte de informação para a pesquisa social}

No texto sobre as estatísticas como fonte de informação para a pesquisa social, Kitsuse e Cicourel (1963) chamam a atenção para o fato de que o desvio em geral e o crime em especial devem ser vistos como produtos da organização social de grupos, estruturas e instituições. Para os autores, o calcanhar de Aquiles dos estudos de criminologia seria a incapacidade de diferenciar a conduta social, que produz uma unidade

\footnotetext{
11 Nesse sentido, ver: Ramos e Musumeci (2005).
} 
de comportamento desviante, da atividade organizacional do sistema de justiça criminal, que produz um registro de crime. A incapacidade dos cientistas sociais em distinguir os crimes que acontecem daqueles que são registrados seria o elemento que impediria 0 avanço da área. Logo, os registros oficiais só poderiam ser usados nas pesquisas sociais se fossem entendidos como representações sociais imperfeitas e, por isso, carentes de confiabilidade e adequação à realidade que eles pretendem representar.

No Brasil, Coelho (1978) foi excessivamente crítico à tendência de alguns profissionais do campo em tomar um número oficial - qualquer que seja ele - como uma verdade em detrimento do resultado de uma série de operações e de interpretações feitas por funcionários públicos. Para ele, qualquer estatística representa uma série de fluxos de decisão sobre registrar ou não um evento, sobre a forma como o fenômeno deve ser registrado e, por fim, sobre como dar sentido ao número oficial. Essas operações tendem a ser mais complexas quando se trata de transformar uma gama de registros já existentes, compilados em formulários administrativos, em estatísticas, sendo esse o problema da quantidade de crimes e criminosos calculada a partir dos dados cedidos pelas polícias ou pela justiça.

No caso das drogas, os policiais são os primeiros a enquadrar um indivíduo preso em flagrante como usuário ou traficante de drogas e, como destacado pela revisão da literatura, essa diferenciação nem sempre ocorre de acordo com a quantidade de substâncias que o indivíduo possui (Campos, 2015), sendo também orientada pela classe social daquele sobre quem recai o rótulo de criminoso (Velho, 1998).

No entender de Misse (2014), a diferenciação entre traficante e usuário obedece à lógica da "sujeição criminal", isto é, dimensões que compõem um perfil social bem delimitado, que tornam, para o sistema de justiça criminal, um sujeito em alguém "propenso a cometer um crime" a qualquer momento. Esses elementos determinariam a classificação do autuado como traficante, enquanto os usuários seriam aqueles que destoariam deste perfil. Pode acontecer de a conduta flagrada pelo policial ser exatamente a mesma em duas situações, mas, como os envolvidos são distintos, a classificação do agente da lei em termos de registros oficiais tende a ser diversa.

Além disso, como é impossível aos agentes policiais e de justiça criminal vigiarem da mesma forma todos os indivíduos em todos os lugares (Paixão, 1982), os dados oficiais padeceriam de uma segunda limitação. Kitsuse e Cicourel (1963) denominam esse viés de camadas de erros entre o comportamento desviante real e o registrado oficialmente. Novamente, refletindo com base na Lei de Drogas, como as áreas de periferias são mais vigiadas pelas polícias do que o restante da cidade, é provável que nelas ocorra a maioria dos flagrantes.

Kitsuse e Cicourel (1963) e Coelho (1978) não são, contudo, contrários ao uso dos registros oficiais como fonte de informação sociológica: eles compartilham o entendimento de que esses números são a voz do Estado e, por isso, apesar dos problemas que a sua produção encobre, seus efeitos, do ponto de vista de produção da realidade social, são muito evidentes. Os autores destacam como os registros oficiais - as queixas registradas 
à polícia, os crimes esclarecidos, os processos iniciados e as prisões efetuadas - são o resultado de um processo de enquadramento, em que o operador do direito diz que determinado indivíduo praticou uma conduta prevista no Código Penal como crime, dando a essa classificação uma série de desdobramentos dentro do sistema de justiça criminal.

Neste artigo utilizamos os registros cedidos pelo Tribunal de Justiça de Minas Gerais para entender como se dá a administração da justiça na cidade de Belo Horizonte. São, em verdade, os registros oficiais que foram copiados em sua totalidade para uma planilha de Excel e, por isso, temos diversas camadas de erros.

A primeira camada de erro é a filtragem operada na fase policial, seja pela existência da sujeição criminal (Misse, 2014), seja pelas representações sociais que os policiais têm sobre quem são os usuários e quem são os traficantes (Velho, 1998), seja pela vontade de registrar ou não o evento e o indivíduo (Batitucci, 2007). É bom lembrar que o Brasil possui duas organizações policiais estaduais: a Militar, responsável pelo policiamento ostensivo e, por conseguinte, a mais propensa à detecção de casos de flagrante, e a Polícia Civil, que é investigativa e judiciária e, por isso, procura esclarecer quem praticou o crime, quando uma ocorrência aparece na delegacia sem um suspeito. Cabe ainda à Polícia Civil reunir provas contra indivíduos que foram flagrados cometendo um delito, para posterior encaminhamento do inquérito policial à justiça.

Toda atividade da Polícia Militar (PM), em termos de identificação de usuários ou traficantes de drogas, deveria ser encaminhada à Polícia Civil para registro, mas isso nem sempre ocorre. Pode acontecer de a própria PM negociar a situação com alguém flagrado com drogas e o registro daquela ocorrência (de uso ou tráfico) jamais ser iniciado (Grillo, Policarpo e Veríssimo, 2011). Pode acontecer de a PM encaminhar o caso e o suspeito para a delegacia de Polícia Civil, e esse policial entender que é melhor liberar o indivíduo, o que impede a sua responsabilização nas fases subsequentes (Paes, 2008). Essas negociações que resultam em filtragem não são "um privilégio da polícia brasileira: os policiais geralmente têm discricionariedade por serem responsáveis pela aplicação da lei" (Paes, 2008 , p. 179). Dessa forma, o filtro policial "é uma prática rotineira e consiste em uma seleção das ocorrências que serão atendidas" pela polícia (p. 179). Em última instância, são os policiais que "dominam as regras do jogo" (Paes, 2008, p. 183), no sentido de serem os responsáveis por indicar quem deve ser registrado e, em seguida, investigado pelo inquérito policial, que será encaminhado ao Judiciário.

Infelizmente, não é possível reconstituir as negociações que têm lugar na fase policial e que resultam no apontamento oficial (ou não) do delito, especialmente, por meio do flagrante. Os registros analisados na seção seguinte são aqueles que concluíram a fase policial, resultando na incriminação de um indivíduo por tráfico ou uso de drogas, o que viabilizou a análise do caso por parte do Poder Judiciário.

Quando um Registro Policial é remetido ao sistema judicial, ele é distribuído a uma instância com competência para a sua análise. Essa distribuição é feita de acordo com o crime em questão, posto a tendência de especialização das cortes de justiça, chamadas de varas no contexto brasileiro. As Varas de Tóxicos foram criadas em Belo Horizonte no ano 
de 2008, dado o aumento exponencial de casos relacionados à Lei 11.343/06 desde a sua publicação. A opção do Tribunal de Justiça de Minas Gerais foi a de criar instâncias especializadas na temática para a promoção de um tratamento mais minucioso da política de drogas. No momento da distribuição dos documentos policiais dentro das Varas de Tóxicos, os funcionários dos cartórios devem identificar qual é o crime em questão, sendo essa a categoria que indexa o procedimento dentro do sistema de justiça.

O segundo recorte dos dados analisados é a própria natureza do formulário de registro da movimentação processual, que possui apenas alguns campos. Se o "sistema impõe um esforço de tradução e padronização" para que os serventuários "só possam classificar da forma como está disponível no sistema" (Paes, 2008, p. 173), a consequência dessa classificação para o cientista social é a restrição da análise às categorias do banco de dados e à qualidade de seu preenchimento. Os campos disponíveis para escrutínio são os relativos à classificação do evento e às datas, com destaque para o dia em que os documentos policiais ingressaram na justiça (determinante no cálculo da prescrição, instituto jurídico que reconhece a perda do direito do Estado em punir alguém pela passagem do tempo) e para o dia em que o procedimento foi encerrado definitivamente (baixado, na linguagem jurídica), informação utilizada para cálculo de produtividade dos tribunais.

A partir do momento em que o procedimento policial ingressa em uma das três Varas de Tóxicos, o Ministério Público pode analisar a documentação e se posicionar quanto ao início do processo penal, a partir do oferecimento da denúncia ou do pedido de arquivamento do inquérito policial. Isso significa que vários procedimentos policiais podem ser encerrados na fase judicial, sem que isso signifique que o processo penal foi propriamente constituído e encerrado com uma sentença de mérito (condenação ou absolvição). A base de dados cedida permite a identificação dessas situações, ao diferenciar o que deu origem a um processo penal do que foi encerrado ainda como inquérito policial. Porém, não é possível saber o que ingressou nas Varas de Tóxicos e ainda não alcançou um desfecho final, sendo este o terceiro recorte das informações empíricas.

Portanto, os dados analisados na próxima seção são resultado "daquilo que a polícia quis registrar" (Paes, 2008, p. 167) e que, em seguida, foi distribuído nas Varas de Tóxicos de Belo Horizonte. Na análise dos documentos policiais pelos serventuários de justiça, eles foram novamente indexados, de acordo com as tipificações previstas na Nova Lei de Drogas, e, dessa forma, as movimentações processuais desse material puderam ser computadas no sistema.

\section{Comércio ou uso de drogas: qual é o padrão de incriminação?}

Os dados cedidos para este artigo são referentes aos processos penais que encontraram um desfecho final em uma das três Varas de Tóxicos de Belo Horizonte entre janeiro de 2008 e setembro de 2015, não sendo mais admissível a sua contestação em 
qualquer instância judicial. A unidade de registro é o procedimento ${ }^{12}$ encaminhado ao Tribunal de Justiça como documentação policial e que, em alguns casos, pôde ser convertido em denúncia pelo Ministério Público, momento a partir do qual se inicia o processo penal.

O banco de dados possui informações pontuais acerca dos envolvidos (nome e sexo), apesar de a maioria ser relacionada à movimentação processual, incluindo-se nessa categoria as datas (de distribuição, denúncia, último julgamento, última movimentação e baixa) e algumas características do processo (classe, motivo do processo e assunto principal). Cabe ressaltar que muitas dessas informações possuem um percentual de preenchimento muito baixo, o que dificultou uma análise mais detalhada desses campos.

O universo de casos contidos no banco analisado era, inicialmente, de 30.579 registros, distribuídos aleatoriamente entre as três varas, cada uma delas com um terço do total de casos. Em consonância com a discussão da literatura sobre o impacto da Lei $11.343 / 06$ nos processos relacionados aos crimes de drogas, notadamente 0 distanciamento dos delitos de uso e tráfico de drogas, optamos por analisar, exclusivamente, os procedimentos classificados como referentes aos artigos 28 (posse de drogas para consumo próprio) e 33 (tráfico de drogas e condutas afins). Os outros casos, concernentes a outros crimes (como a fabricação, por exemplo), foram excluídos da análise. Também foram excluídos os procedimentos encerrados antes de janeiro de 2008, quando as Varas de Tóxicos foram oficialmente criadas.

Após a aplicação desses dois filtros, foram excluídos 1.124 casos, o que representa $3,7 \%$ do total dos registros cedidos pelo TJMG. Restaram 29.618 casos, que correspondem a procedimentos encerrados entre janeiro de 2008 e setembro de 2015 , enquadrados como "posse de drogas para consumo pessoal" ou "tráfico de drogas e condutas afins".

Com a entrada em vigor da Lei 11.343/06, observam-se tendências divergentes quando comparados os dois tipos de tipificação principal dos documentos recebidos da Polícia Judiciária (Gráfico 1). A análise dos números absolutos (barras, Gráfico 1) exige duas ressalvas. Primeiro, as varas foram constituídas em 2008 e, por isso, é de esperar que a sua capacidade plena de operação seja atingida no ano seguinte, quando as suas rotinas já estão institucionalizadas e os processos de tráfico de drogas, inicialmente distribuídos em outras varas, foram transferidos para as especializadas. Segundo, após os filtros aplicados, o banco de dados diz respeito aos casos que foram encerrados entre janeiro de 2008 e setembro de 2015, o que significa que as Varas de Tóxicos podem receber um contingente crescente de procedimentos policiais ao longo da série histórica, mas, como o seu padrão de decisão tende a ser flutuante, dependendo, por exemplo, da

\footnotetext{
12 São três as situações em que o procedimento policial é encaminhado ao Judiciário para distribuição: (1) prisão em flagrante, já que o juiz deve se manifestar pela sua transformação em prisão ou liberdade provisória; (2) solicitação de dilação de prazo, para continuidade da investigação policial que não foi encerrada no prazo estabelecido em lei; (3) encerramento do inquérito policial, quando os indícios coletados na fase policial são encaminhados ao Judiciário para que este envie a documentação ao Ministério Público para oferecimento da denúncia, momento a partir do qual se inicia o processo penal.
} 
quantidade de promotores, defensores, juízes disponíveis para o trabalho, é essa tendência que aparece no Gráfico $1^{13}$.

Em termos percentuais, a categoria "tráfico de drogas e condutas afins", em todo o período pesquisado, é a que possui a maior recorrência, representando quase $100 \%$ dos dados no último ano da série. Por sua vez, a categoria "posse de drogas e condutas afins" correspondia a $8 \%$ dos casos no início do período e chega ao final deste com uma frequência perto de $0 \%$ (Gráfico 1). Duas são as explicações possíveis para esse padrão.

Uma primeira explicação seria a de que os casos de "porte de drogas para uso pessoal" deixaram de ser encaminhados para as Varas de Tóxicos e passaram a ser destinados aos Juizados Especiais Criminais (Jecrim), pois são crimes de menor potencial ofensivo sujeitos às medidas despenalizadoras citadas anteriormente. Como a concessão do sursis ou da suspensão condicional do processo impede o registro do procedimento no banco de dados nessas situações, é como se o "delito" jamais tivesse existido. Assim, os casos enquadrados como uso de drogas, encaminhados às Varas de Tóxicos, seriam aqueles em que o usuário descumpriu a medida, sob os quais se tinha dúvida sobre a diferença entre uso e tráfico ou ainda casos em que o usuário também era traficante ${ }^{14}$. Como os dados do Jecrim não podem ser acessados em razão da forma como as medidas despenalizadoras operam, podemos apenas lançar essa hipótese para teste em futuras pesquisas sobre o tema.

Uma segunda explicação pode ser a de que, nos anos seguintes à entrada da Nova Lei de Drogas, as Varas de Tóxicos receberam mais procedimentos policiais nos quais o "porte de drogas para uso pessoal" vinha combinado com o "tráfico de drogas". Porém, essa classificação dos procedimentos cai em desuso até ser praticamente abandonada no ano de 2015. Assim, apesar da diversidade de delitos de drogas previstos na lei e, principalmente, dos esforços de diferenciação no tratamento dirigido a usuários e traficantes, haveria uma aplicação generalizada da categoria "tráfico de drogas e condutas afins" a praticamente todos os procedimentos remetidos pela polícia à justiça.

\footnotetext{
13 De acordo com as informações disponíveis no site do Tribunal de Justiça de Minas Gerais (TJMG), cada Vara de Tóxicos conta com um juiz e dois promotores. Para maiores informações, ver: <http://www9.tjmg.jus.br/portal/acoes-e-programas/gestao-de-primeira/varas-de-toxicos/>. Acesso em: 11 maio 2016.

14 Lei 11.343/2006, Art. 48, § 1 o O agente de qualquer das condutas previstas no art. 28 desta Lei, salvo se houver concurso com os crimes previstos nos arts. 33 a 37 desta Lei, será processado e julgado na forma dos arts. 60 e seguintes da Lei n 9.099, de 26 de setembro de 1995, que dispõe sobre os Juizados Especiais Criminais.
} 


\section{Gráfico 1}

Procedimentos de acordo com a tipificação do delito e o ano de distribuição (número absoluto e percentual) - Varas de Tóxicos de Belo Horizonte (jan./2008 e set./2015)

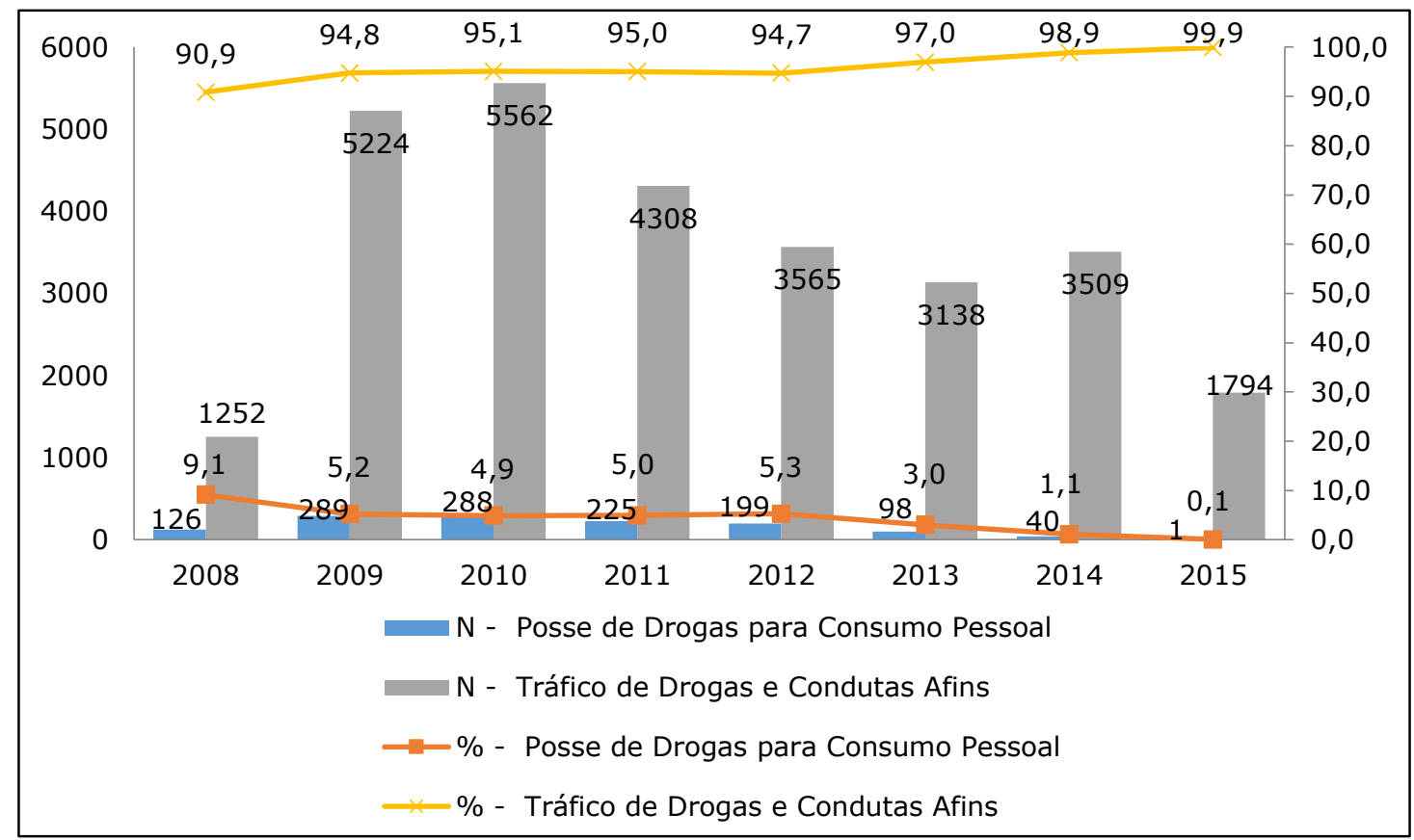

Fonte: Elaboração própria com base em dados cedidos pelo Tribunal de Justiça de Minas Gerais. Qui-quadrado = 289,444 (sig. 0,000).

Resultado semelhante foi encontrado por Jesus et al. (2011), que, ao analisarem especificamente autos de prisão em flagrante em São Paulo, encontraram $76 \%$ de casos enquadrados como tráfico de drogas. Ainda assim, os percentuais de São Paulo são inferiores, já que, em Belo Horizonte, os procedimentos policiais que foram encaminhados às Varas de Tóxicos, a partir de 2014, dizem respeito quase que exclusivamente aos casos de tráfico de drogas. Alternativamente, esses dados podem estar indicando o "desenrolo", categoria criada por Grillo, Policarpo e Veríssimo (2011) para a descrição das situações em que há o flagrante por uso de drogas, mas os policiais negociam a liberação do indivíduo, sem que essa situação se transforme em um registro oficial. Em resumo, como os dados do Jecrim são sigilosos, as informações do Gráfico 1 permitem somente especulações sobre a tendência da polícia em classificar os indivíduos como usuários ou traficantes.

Outra forma de entender a quantidade de encaminhamentos realizados às Varas de Tóxicos é calculando a taxa de "porte de drogas para uso pessoal" e de "tráfico de drogas e condutas afins" por 100 mi habitantes. Apesar de a unidade de análise ser o procedimento, e não o indivíduo envolvido - já que um mesmo procedimento pode contar com vários indivíduos -, essa medida é interessante por dar uma ideia da prevalência do fenômeno dentro da população (Gráfico 2). 
Utilizando como base de comparação as taxas de Marinho et al. (2014, p. 33-34), calculadas para o país a partir das informações policiais disponíveis no Sistema Nacional de Estatísticas em Segurança Pública e Justiça Criminal (SINESPJC) do Ministério da Justiça, constata-se que, em 2010, a taxa de tráfico de drogas por 100 mil habitantes era 43,7 no Brasil e 234 em Belo Horizonte, o que significa dizer que a capital mineira tinha taxas de tráfico cinco vezes maiores que a média nacional. Nesse mesmo ano, a taxa de crimes de uso de drogas por 100 mil habitantes era de 35,7 no país e de 12 em Belo Horizonte. Então, o Gráfico 2 demonstra que o trabalho das organizações policiais que deságua no Judiciário, no âmbito da Lei de Drogas, parece ser majoritariamente o relacionado ao tráfico de drogas.

\section{Gráfico 2}

Taxas por $\mathbf{1 0 0 . 0 0 0}$ habitantes para os procedimentos tipificados como "porte de drogas para uso pessoal" e de "tráfico de drogas e condutas afins" - Varas de Tóxicos de Belo Horizonte (jan./2008 e set./2015)

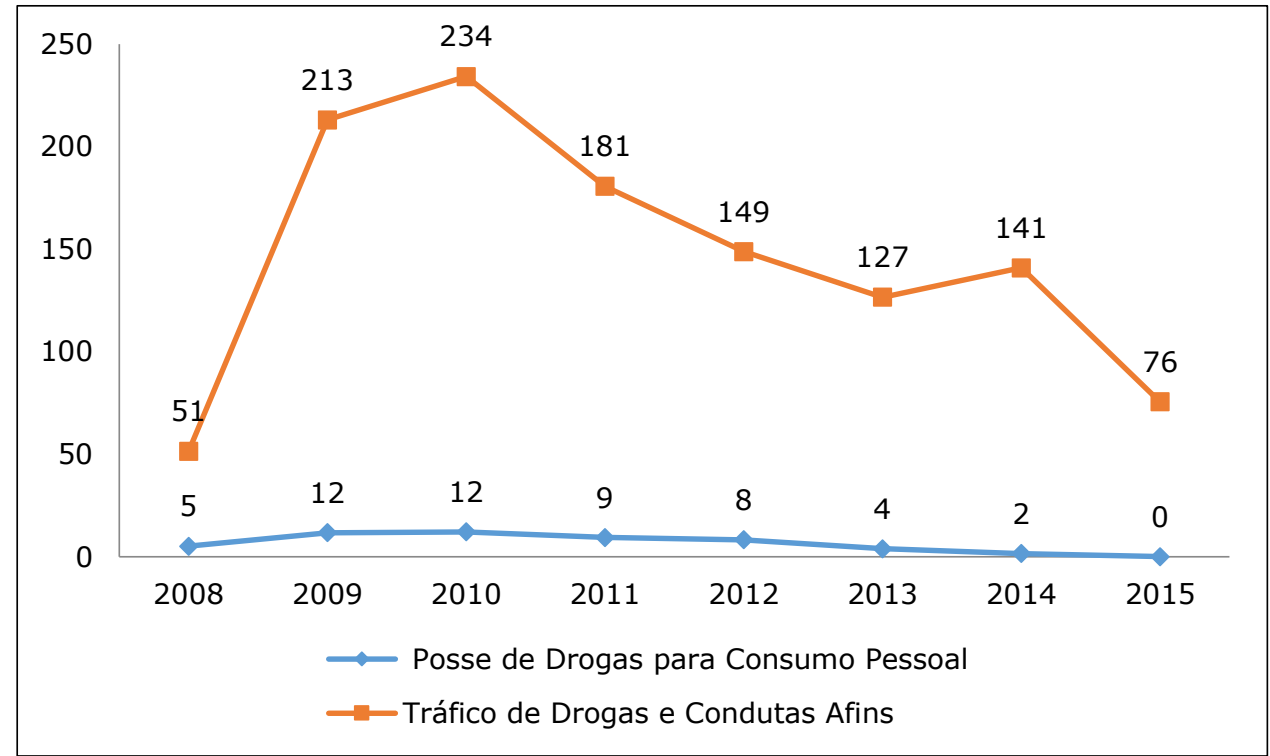

Fonte: Elaboração própria com base em dados cedidos pelo Tribunal de Justiça de Minas Gerais (procedimentos) e pelo Índice Mineiro de Responsabilidade Social (População).

Utilizando o mesmo recorte - "posse de drogas para consumo pessoal" e "tráfico de drogas e condutas afins" para procedimentos encerrados entre 2008 e 2015 -, percebeu-se uma predominância de casos cujos envolvidos são do sexo masculino (75\%), contra $7 \%$ de envolvidos do sexo feminino e 3\% de envolvidos de ambos os gêneros. Há muito descomprometimento na aferição/preenchimento dos dados de sexo quando a classificação do crime é posse de drogas para consumo pessoal, dado que a falta de informação é de $87 \%$ nesses casos, enquanto a não informação equivale a $12 \%$ quando o delito é classificado como tráfico de drogas e condutas afins (Gráfico 3). 


\section{Gráfico 3 \\ Percentual de procedimentos de acordo com a tipificação do delito e o sexo do envolvido - Varas de Tóxicos de Belo Horizonte (jan/2008 e set/2015) (\%)}

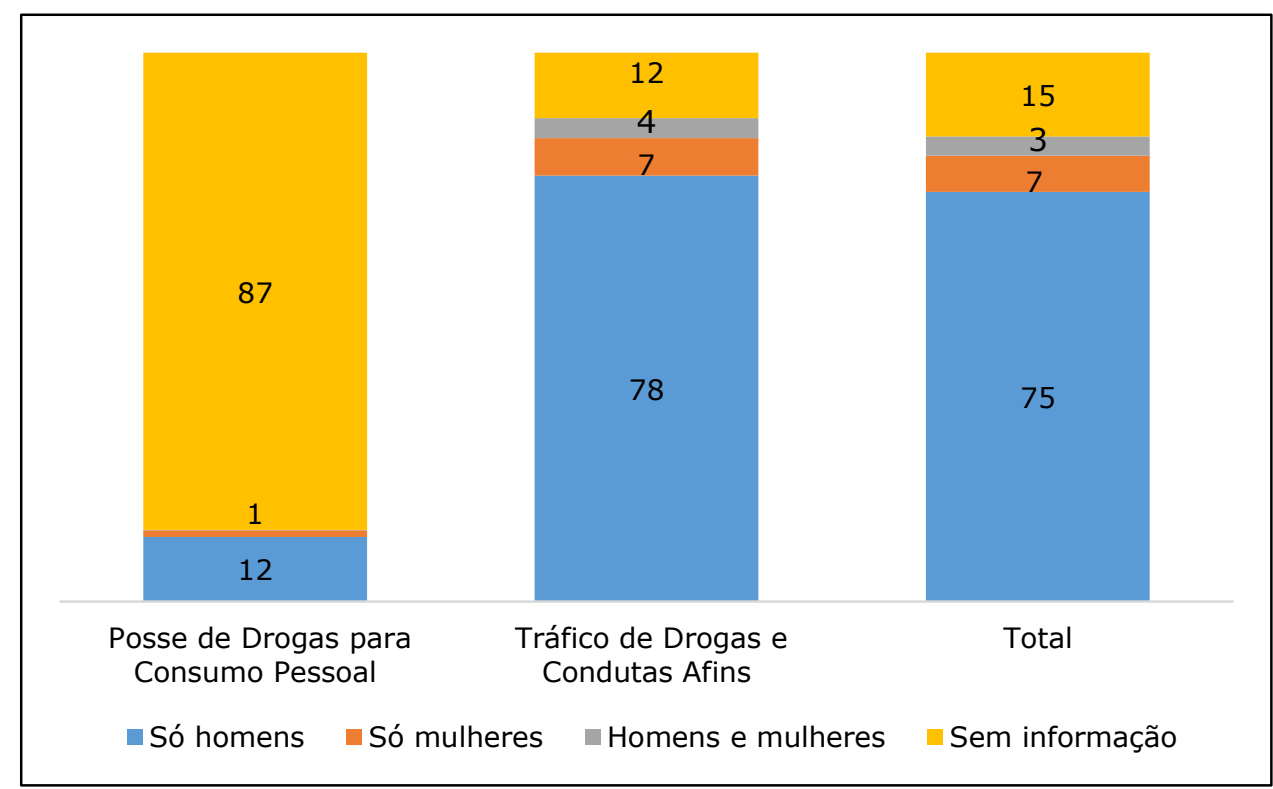

Fonte: Elaboração própria com base em dados cedidos pelo Tribunal de Justiça de Minas Gerais. Qui-quadrado $=5400,36($ sig. 0,000).

A mesma análise acerca dos envolvidos por "tráfico de drogas e condutas afins", feita pelo total de indivíduos revelou que, descontados aqueles casos sem informação $(15 \%)$ e os processos em que há pessoas de ambos os sexos (3\%), mantém-se a esperada predominância de envolvidos do sexo masculino (92\%), enquanto as envolvidas do sexo feminino representam 8\%. Essa distribuição difere da encontrada por Boiteux et al. (2009), tanto no estado do Rio de Janeiro, com $79,3 \%$ de homens e $20,7 \%$ mulheres, como no Distrito Federal, que teve $73,2 \%$ de envolvidos do sexo masculino e $26,8 \%$ do sexo feminino, mais que o triplo do percentual de mulheres computadas nos procedimentos das Varas de Tóxicos em Belo Horizonte. Embora existam divergências nas distribuições da categoria sexo entre as localidades, há uma tendência similar de que a maioria dos envolvidos nos procedimentos policiais encaminhados ao Judiciário seja do sexo masculino.

A segunda variável elencada no perfil foi a existência de mais de um procedimento relacionado ao mesmo indivíduo. Esses sujeitos não podem ser considerados reincidentes porque o Código Penal reserva essa nomenclatura a quem, depois de ter recebido uma sentença condenatória que não pode ser questionada (transitada em julgado), comete novo crime ${ }^{15}$, o que não pode ser dito sobre os envolvidos que estão no banco de dados, já que só temos a informação da movimentação processual atual. Assim, para a criação da variável "número de procedimentos" foi considerado o nome do indivíduo, sendo que a sua

${ }^{15} \mathrm{CP}$, Art. 63 - Verifica-se a reincidência quando o agente comete novo crime, depois de transitar em julgado a sentença que, no País ou no estrangeiro, o tenha condenado por crime anterior. 
repetição mais de uma vez no banco indicava que aquele sujeito estava envolvido em mais de um crime de posse ou tráfico.

Cabe esclarecer que essa análise contou a repetição de nomes iguais, sendo impossível fazer mais que isso, dada a ausência de outros dados que pudessem identificar os envolvidos (número de documentos pessoais, por exemplo). Desta forma, a distribuição expressa a seguir, embora pouco provável, pode sofrer variações se por ventura existirem muitos homônimos. Tendo essa consideração em mente, pode-se afirmar que pouco mais que um terço $(36,2 \%)$ dos indivíduos possuem mais de um procedimento nas Varas de Tóxicos e $63,8 \%$ possuem somente um procedimento. Os indivíduos com maior prevalência no período estudado registraram dez procedimentos diferentes no intervalo de tempo 2008-2015 (Gráfico 4):

\section{Gráfico 4 \\ Percentual de procedimentos de acordo com a tipificação do delito e a quantidade de aparições que o indivíduo possui - Varas de Tóxicos de Belo Horizonte (jan/2008 e set/2015) (\%)}

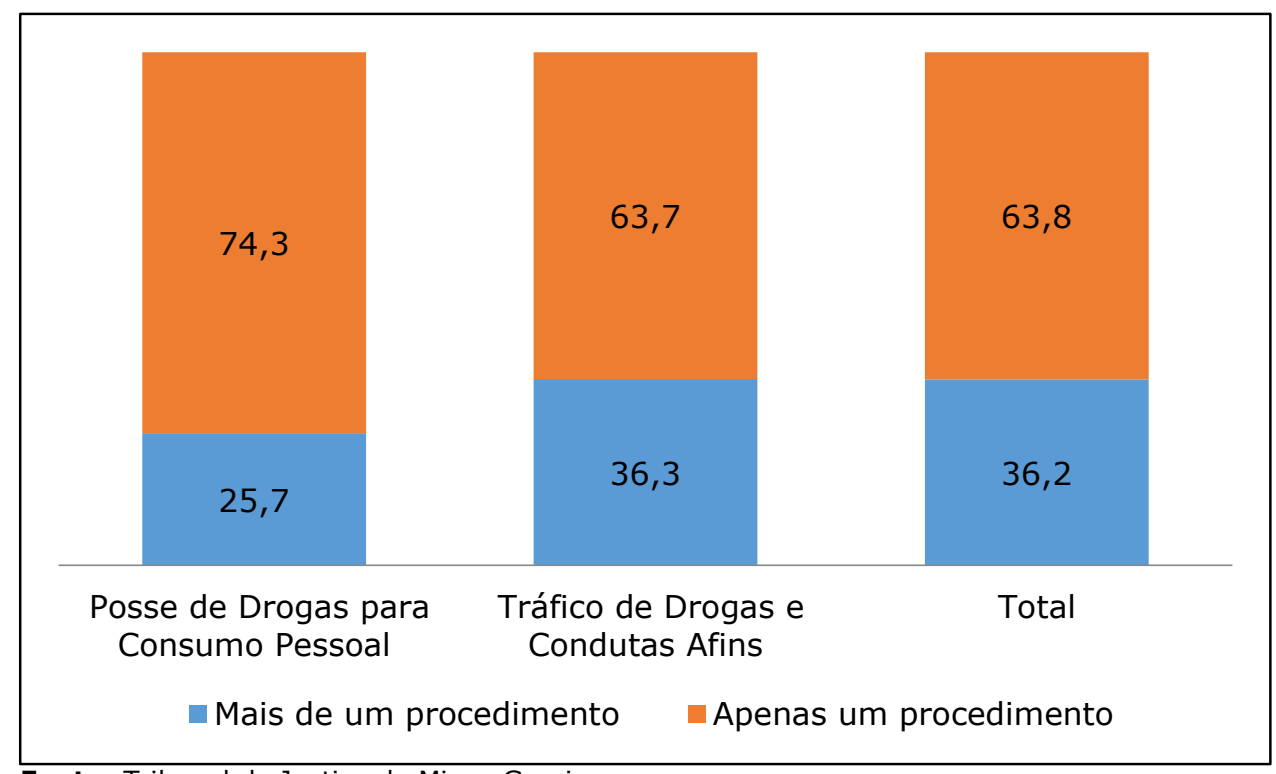

Fonte: Tribunal de Justiça de Minas Gerais.

Qui-quadrado = 8,021 (sig. 0,003).

A busca por registros duplicados foi utilizada por Campos (2015) para traçar o perfil dos autuados por tráfico e uso de drogas em São Paulo entre 2004 e 2009. Diante de um resultado semelhante ao do Gráfico 4, o autor argumenta que nas situações extremas, em que um mesmo indivíduo possui muitos registros, estamos diante de uma carreira criminal, em que o sujeito é autuado pela polícia e, antes mesmo de sua condenação, já foi registrado novamente. 
Ainda em relação ao montante de procedimentos de tráfico e posse de drogas encerrados entre 2008 e 2015, buscou-se analisar o papel da prisão em flagrante ${ }^{16}$. Devido às limitações do banco de dados, foi possível identificar com certeza que em cerca de $60 \%$ dos procedimentos o flagrante estava presente. Todavia, como essa variável não foi preenchida de maneira uniforme, a parcela pode ser mais expressiva. Mesmo reconhecendo o problema, optou-se por comparar os casos de flagrante com o restante do banco (assumindo que não sejam flagrantes). O resultado disposto no Gráfico 5 era razoavelmente esperado:

Gráfico 5

Percentual de procedimentos de acordo com a tipificação do delito e a presença do flagrante - Varas de Tóxicos de Belo Horizonte (jan/2008 e set/2015) (\%)

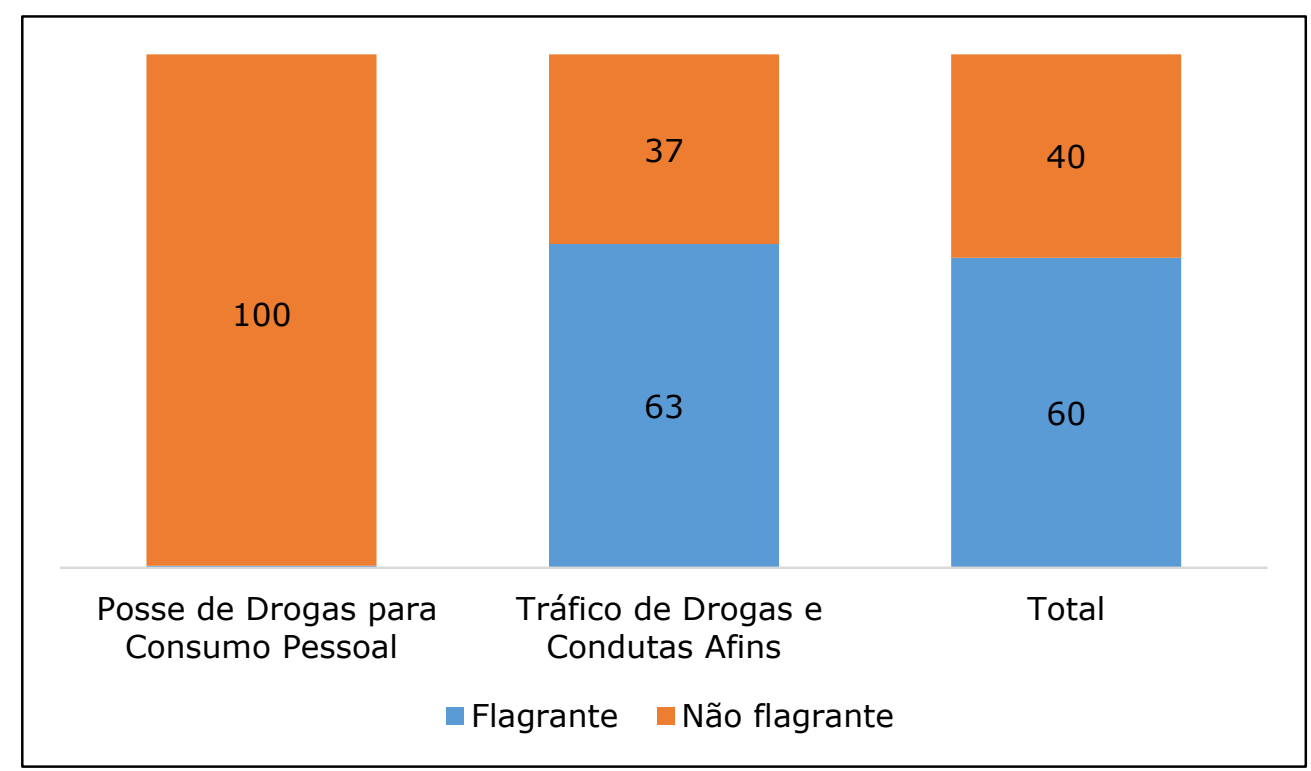

Fonte: Elaboração própria com base em dados cedidos pelo Tribunal de Justiça de Minas Gerais. Qui-quadrado = 1992,80 (sig. 0,000).

De acordo com Grillo, Policarpo e Veríssimo (2011, p. 137), desde o início da aplicação da Nova Lei, existe uma tendência de "queda nos registros de ocorrência por flagrante de uso de drogas", já que "a administração dos mesmos teria ficado sob a responsabilidade da Polícia Militar, instituição que realiza o policiamento ostensivo, atuando na ponta do sistema de justiça criminal". Os autores indicam que a prioridade, do ponto de vista de procedimentos policiais que são encaminhados para a justiça, é o tráfico de drogas e, por isso, os casos de uso terminariam negociados pela PM, sem o encaminhamento do indivíduo e da situação para a delegacia de polícia e, por fim, para o

\footnotetext{
${ }^{16}$ Apesar de utilizarmos o flagrante como ponto de análise do funcionamento do sistema de justiça criminal, não podemos problematizar a qualidade do Auto de Prisão em Flagrante Delito (APFD). Afinal, este artigo foi produzido a partir da base de dados cedida pelo Tribunal de Justiça de Minas Gerais e não a partir dos documentos que compõem o processo penal, o que impede qualquer escrutínio de como os flagrantes são produzidos pelas Polícias Militar e Civil em Belo Horizonte.
} 
Judiciário. Consequentemente, esse tipo de procedimento desapareceria progressivamente dos registros judiciais.

A explicação de Grillo, Policarpo e Veríssimo (2011) para a prevalência dos flagrantes nos casos de tráfico de drogas no Rio de Janeiro parece encontrar ressonância na cidade de Belo Horizonte. Afinal, as ocorrências de posse para uso diminuem ao longo do período analisado e praticamente não contam com a presença do flagrante. Seriam os acertos informais entre policiais e usuários, em casos em que a droga já foi consumida ou dispensada no momento da abordagem, que explicariam, simultaneamente, a baixa quantidade de procedimentos de posse para uso e o fato de a quase totalidade desses procedimentos não contar com o flagrante.

No tráfico de drogas praticamente dois terços $(63,1 \%)$ dos procedimentos foram abertos por flagrante, um percentual muito mais elevado que o observado em outras modalidades de crime em Belo Horizonte, como, por exemplo, o homicídio doloso, no qual apenas $26 \%$ dos inquéritos policiais foram iniciados por flagrante (Ribeiro et al., 2014). Contudo, trata-se de percentual semelhante ao encontrado em outras pesquisas sobre tráfico de drogas, em que a quantidade de flagrantes responde por dois terços do total de processos iniciados (Lemgruber e Fernandes, 2015). Esse resultado pode indicar uma prioridade das instituições policiais para casos envolvendo tráfico de drogas, o que aumentaria a vigilância sobre certos grupos (em detrimento de uma atenção espraiada entre todas as modalidades de crime e segmentos populacionais) e, consequentemente, a quantidade de flagrantes.

De outro lado, como "é baixa a capacidade de incriminação da justiça brasileira, cujo maior gargalo é a fase policial" (Vargas, 2014, p. 421), os procedimentos de tráfico examinados pelo Judiciário são aqueles em que existe alguma chance de um desfecho útil, em que os indícios coletados no flagrante resultem em algum tipo de condenação, o que explicaria a prevalência desse tipo de caso no banco de dados. Na próxima seção, problematizaremos um pouco mais essa situação.

\section{Processando o tráfico de drogas: os determinantes do tempo}

Os dados analisados na seção anterior indicaram que (i) os procedimentos policiais encaminhados às Varas de Tóxicos de Belo Horizonte são prioritariamente relativos ao "tráfico de drogas e condutas afins", já que a categoria "posse de drogas para consumo pessoal" responde por $4,3 \%$ dos casos incluídos no banco de dados do TJMG; (ii) os casos de tráfico de drogas envolvem, majoritariamente, homens, com apenas um procedimento enquadrado na Lei 11.343/06 e que foram autuados em flagrante.

Nesta seção optamos por analisar exclusivamente o andamento dos procedimentos policiais de "tráfico de drogas e condutas afins" encaminhados às Varas de Tóxicos de Belo Horizonte e encerrados entre janeiro de 2008 e setembro de 2015. A opção por tratar somente o tráfico deve-se à diferenciação introduzida pela Lei 11.343/06 nos institutos jurídicos cabíveis para cada um dos dois tipos penais, com especial destaque para a não 
aplicação da pena de prisão aos usuários. Portanto, serão considerados como fonte de informação para esta seção 28.352 casos, referentes aos procedimentos enquadrados na categoria "tráfico de drogas e condutas afins".

A nossa hipótese é a de que a forma de construção do registro de tráfico de drogas (flagrante ou não) tem implicações no tempo do processo penal, contribuindo para um fluxo no formato de um cilindro (com muitos processos iniciados e encerrados com uma sentença válida) em detrimento de um funil (com muitos processos iniciados e poucas sentenças válidas ${ }^{17}$.

As Varas de Tóxicos são responsáveis por dar um destino final às investigações realizadas pela Polícia Civil. Nesse sentido, elas recebem o material produzido pela polícia (1) no momento da lavratura do flagrante, pois cabe ao juiz determinar se o indivíduo deve permanecer preso provisoriamente ou se ele pode responder ao processo em liberdade ${ }^{18}$, (2) quando o delegado não foi capaz de concluir a investigação no prazo de 30 dias, se o suspeito estiver preso ou 90 dias quando o suspeito estiver solto, ocasião em que a autorização policial deve solicitar a extensão do prazo, ou a dilação no jargão judicial ${ }^{19}$; (3) quando o delegado tiver concluído a sua tarefa, cabendo ao promotor decidir sobre a denúncia ou encerramento da investigação, já que a polícia não pode arquivar o inquérito policial ${ }^{20}$.

Cabe ao serventuário da Vara de Tóxicos receber os documentos vindos da polícia e encaminhá-los ao promotor de justiça, para que ele possa decidir o que fazer: (i) se solicitar o arquivamento ao juiz; (ii) se denunciar, iniciando o processo penal; (iii) se devolver o procedimento à delegacia, para que novas diligências sejam realizadas ${ }^{21}$. Os casos que retornaram à delegacia não se encontram nesse banco de dados, que contempla somente os procedimentos que receberam um desfecho final por parte do Judiciário.

O banco de dados do TJMG permite a identificação dos inquéritos policiais que resultaram em processo a partir de duas variáveis: uma que diz se o procedimento se encerrou como inquérito ou processo, e outra que diz por que isso ocorreu. Do total de casos analisados, tão somente $5 \%$ ( 1.410 casos) não redundaram em processos: foram encerrados antes mesmo da denúncia do promotor como inquéritos policiais. A título de comparação, os casos de homicídio doloso que são encerrados como inquérito policial, dado o não esclarecimento da autoria, correspondem a quase $54 \%$ dos registros existentes

17 Para uma revisão conceitual e diferenciação de fluxos no formato de cilindro e funil ver: Neubacher et al. (1999).

18 Código de Processo Penal (CPP), Art. 306. A prisão de qualquer pessoa e o local onde se encontre serão comunicados imediatamente ao juiz competente, ao Ministério Público e à família do preso ou à pessoa por ele indicada.

19 Lei $11.343 / 2006$, Art. 51 . O inquérito policial será concluído no prazo de 30 (trinta) dias, se o indiciado estiver preso, e de 90 (noventa) dias, quando solto. Parágrafo único. Os prazos a que se refere este artigo podem ser duplicados pelo juiz, ouvido o Ministério Público, mediante pedido justificado da autoridade de polícia judiciária.

${ }^{20} \mathrm{CPP}$, Art. 17. A autoridade policial não poderá mandar arquivar autos de inquérito.

${ }^{21}$ Lei 11.343/2006, Art. 54. Recebidos em juízo os autos do inquérito policial, de Comissão Parlamentar de Inquérito ou peças de informação, dar-se-á vista ao Ministério Público para, no prazo de 10 (dez) dias, adotar uma das seguintes providências: I - requerer o arquivamento; II - requisitar as diligências que entender necessárias; III - oferecer denúncia, arrolar até 5 (cinco) testemunhas e requerer as demais provas que entender pertinentes. 
no banco de dados do TJMG (Ribeiro, Moara e Campos, 2017). Em suma, a filtragem (registros policiais que não se convertem em processos penais) é baixíssima nos casos de tráfico de drogas, o que confirma o fluxo de processamento em formato de cilindro em detrimento do formato de funil.

Cabe destacar que o encerramento do caso de tráfico de drogas como inquérito policial não foi por pedido de arquivamento por parte do Ministério Público, como ocorre nos casos de homicídio doloso. A principal razão apontada para o encerramento antes do processo foi a extinção da punibilidade dada pela prescrição ( $80 \%$ do total de Inquéritos ou 1.129), que é a perda do direito do Estado de dar andamento ao processo penal em razão do decurso do tempo. Esse fenômeno pode ser visto como a representação máxima do brocardo jurídico "o direito não socorre aos que dormem". Nesse caso, o direito não socorreu aos promotores de justiça, que tardaram demais para oferecer a denúncia e, com isso, perderam o direito de processar os indivíduos envolvidos na prática do tráfico de drogas. Para as análises seguintes, os casos encerrados como inquérito foram excluídos, já que eles não se converteram em processos.

Considerando os procedimentos policiais que redundaram em processos $(26.942$ casos), o foco passou a ser o tempo para uma decisão final por crime de tráfico de drogas. Nesse ponto, impõe-se a equalização do tempo com a própria ideia de justiça: se o processo é rápido demais, ele obsta o direito de defesa dos acusados, impedindo a produção de provas que possam levar a uma absolvição (Adorno e Pasinato, 2007). Se o processo é moroso demais, ele se torna uma representação da injustiça, já que a decisão não produzirá efeitos pedagógicos sobre aquele que cometeu o delito (idem). Então, o tempo do processo deve equalizar tanto o direito de defesa dos cidadãos como a utilidade da punição (Machado, Zackseski e Raupp, 2016).

De acordo com os prazos estabelecidos pela Lei 11.340/2006, o inquérito policial deve se encerrar em 30 dias (se o réu estiver preso) ou em 90 dias (se o réu estiver solto). Em seguida, o inquérito policial é encaminhado para o Judiciário, quando será distribuído e, depois, enviado para o promotor de justiça que deverá oferecer sua denúncia em 10 dias, cabendo ao juiz recebê-la ou recusá-la. Depois do aceite da denúncia, são concedidos 10 dias para a notificação do acusado e apresentação da resposta à acusação ${ }^{22}$. A audiência de instrução e julgamento deve ser realizada em até 30 dias após o recebimento da denúncia ${ }^{23}$, abrindo-se um prazo de 10 dias para que o juiz profira a sua sentença ${ }^{24}$. Numa contabilidade superficial, os prazos para a primeira sentença no processo de tráfico de

\footnotetext{
22 Lei 11.340/2006, Art. 55. Oferecida a denúncia, o juiz ordenará a notificação do acusado para oferecer defesa prévia, por escrito, no prazo de 10 (dez) dias.

${ }^{23}$ Lei 11.340/2006, Art. 56. Recebida a denúncia, o juiz designará dia e hora para a audiência de instrução e julgamento, ordenará a citação pessoal do acusado, a intimação do Ministério Público, do assistente, se for o caso, e requisitará os laudos periciais. § 2ㅇ A audiência a que se refere o caput deste artigo será realizada dentro dos 30 (trinta) dias seguintes ao recebimento da denúncia, salvo se determinada a realização de avaliação para atestar dependência de drogas, quando se realizará em 90 (noventa) dias.

24 Lei 11.340/2006, Art. 58. Encerrados os debates, proferirá o juiz sentença de imediato, ou o fará em 10 (dez) dias, ordenando que os autos para isso Ihe sejam conclusos.
} 
drogas são de 150 dias para o réu solto e 90 dias para o réu preso (Jesus et al., 2011, p. 81).

Os estudos existentes sobre tempo de processamento no Brasil destacam como a morosidade é uma característica estrutural e estruturante do nosso sistema de justiça criminal (Vargas, 2014), com impactos perversos do ponto de vista da eficiência, efetividade e eficácia na prevenção e repressão de delitos (Costa, 2015). O decurso do tempo pode significar injustiça se o procedimento for rápido demais, pois significa que não foi dado ao indiciado todas as oportunidades de uma defesa qualificada; se o procedimento for longo demais, ele também se qualifica em injustiça, dada a prescrição que, por sua vez, implica a extinção da punibilidade (quando o réu, apesar de condenado, não irá cumprir pena) e, por conseguinte, sentimento de impunidade (Adorno e Pasinato, 2007).

Para entender se o tráfico de drogas é administrado de forma rápida ou morosa, inicialmente foram pensadas cinco análises, que correspondem às etapas marcantes de um processo penal. No entanto, as mensurações do tempo despendido entre a data de distribuição e a data da denúncia, assim como dos tempos transcorridos entre a denúncia e o último julgamento e entre a denúncia e a baixa definitiva do processo foram prejudicadas pelo baixo percentual de preenchimento dos campos (menos de $10 \%$ ). Optamos, assim, por não analisar mais a fundo esses intervalos de tempo. A mensuração de tempo na qual obtivemos informações de qualidade foi a que contempla o espaço temporal entre a data de distribuição e a data de baixa do processo, dados que possuíam $100 \%$ de preenchimento.

O tempo médio entre a chegada do inquérito policial (distribuição) e o encerramento do processo, após uma sentença final da qual não cabe qualquer tipo de recurso (baixa), é de 179 dias, aproximadamente seis meses (Tabela 1), limite temporal bastante próximo ao estabelecido pela lei 11.343/2006 (cujo prazo é de 150 dias até a primeira audiência). Esse tempo é muito semelhante ao computado por Jesus et al. (2011, p. 81) na análise dos casos de tráfico de drogas iniciados por flagrante em São Paulo, quando o tempo de processamento ficou em torno de 142 dias.

Tabela 1

Estatísticas descritivas do tempo entre a data da distribuição e a data de baixa dos processos de tráfico de drogas - Varas de Tóxicos de Belo Horizonte (jan/2008 e set/2015)

\begin{tabular}{|l|c|c|c|c|c|c|c|}
\hline & N & Mínimo & Máximo & Média & $\begin{array}{c}\text { Desvio } \\
\text { Padrão }\end{array}$ & Mediana & Moda \\
\hline $\begin{array}{l}\text { Tempo } \\
\text { entre a } \\
\text { distribuição } \\
\text { e a baixa }\end{array}$ & 26942 & 1 & 2514 & 179 & 355 & 43 & 35 \\
\hline
\end{tabular}

Fonte: Elaboração própria com base em dados cedidos pelo Tribunal de Justiça de Minas Gerais.

A mediana, valor que divide em dois a série ordenada por valores crescentes de tempo, foi de 42 dias, o que significa dizer que metade dos procedimentos policiais encaminhados ao judiciário foi encerrada em menos de dois meses. A moda, que é o valor 
mais frequente na distribuição, foi de 35 dias, ou seja, pouco mais de um mês. Em outras palavras, uma vez que o procedimento policial é recebido pelo Judiciário, o tempo para sua análise é excessivamente curto.

Além disso, o tempo de processamento do tráfico de drogas é substantivamente menor do que o verificado em outros crimes, mesmo quando considerada apenas a fase entre a distribuição e a baixa. Em Belo Horizonte, nos casos de homicídio doloso, o tempo despendido nessa etapa é, em média, de 3.319 dias, um pouco menos de uma década (Ribeiro, Moara e Campos, 2017). Assim, a pergunta que se coloca é como explicar que o processo de tráfico de drogas tem tempo 18,6 vezes menor do que o homicídio doloso, se o procedimento de instrução e julgamento não se diferencia tanto?

A primeira explicação, de cunho mais microssociológico, poderia ser buscada na construção social do traficante como inimigo da sociedade, tal como delineada inicialmente por Velho (1998) e reificada com o conceito de sujeição criminal de Misse (2014). Como o traficante é visto como o grande inimigo, que precisa ser combatido a qualquer custo, é nesse sujeito que o sistema penal deve concentrar seus esforços, o que explicaria a grande quantidade de presos provisórios (Azevedo e Cifali, 2015), o rápido processamento (Jesus et al., 2011) e, ainda, o elevado percentual de condenados por esse delito (Lemgruber e Fernandes, 2015).

A segunda explicação, de cunho macrossociológico, é a apresentada por Sapori (1995), que denomina o funcionamento das varas criminais de Belo Horizonte como "justiça em linha de montagem". Essa categoria serviria para identificar a rapidez com que determinados casos são processados em razão do tratamento que é dado aos processos criminais pelos operadores do direito (juízes, promotores e defensores). Esses operadores desconsiderariam as especificidades do crime e do criminoso, tratando todos os processos de um determinado tipo (por exemplo, tráfico de drogas) de forma semelhante, o que aumentaria a quantidade de casos "solucionados" diariamente. Nesse contexto, o processo não visaria à ampla defesa, já que juízes e promotores não problematizariam as categorizações policiais e não abririam espaço para argumentação por parte dos defensores públicos, como verificado por Jesus et al. (2011). A justificativa para essa opção seria a eficiência, pois, agindo dessa maneira, nem a morosidade nem a impunidade se consubstanciariam, já que as varas processariam os casos rapidamente e os puniriam de forma exemplar (Costa, 2015). Nas palavras do autor:

$\mathrm{Na}$ justiça linha de montagem as individualidades dos processos são desconsideradas, sendo que prevalece o tratamento categorizado deles. A partir disso são empregadas técnicas padronizadas que permitem o despacho dos processos de forma seriada, em grande quantidade e num curto intervalo de tempo (Sapori, 1995, p. 146).

Anualmente, são encerrados 3.368 processos de tráfico de drogas nas três Varas de Tóxicos de $\mathrm{BH}$. Boa parte desses casos foi remetida pela polícia naquele mesmo ano, dado que a média de tempo entre a data da distribuição e a data da baixa é de 179 dias. 
Além disso, $79 \%$ desses processos foram encerrados sob o signo "procedimento criminal findo", o que significa dizer que houve uma sentença de mérito, aquela que julga substantivamente os envolvidos, condenando-os ou absolvendo-os. O problema é que o banco de dados não nos permite conhecer esse desfecho e, portanto, não podemos assertivamente dizer que a tendência das Varas de Tóxicos é condenar os registrados pela polícia como traficantes de drogas. Porém, como o percentual de encarcerados por esse delito é elevado nas penitenciárias que acolhem os detentos de Belo Horizonte, é possível indicar que a tendência das Varas de Tóxicos parece ser a condenação.

Por outro lado, os dados existentes no banco do TJMG permitem o teste da hipótese de "justiça em linha de montagem" no quesito de determinantes do tempo. No imaginário dos operadores da justiça, o perfil do traficante é de homens que praticam esses delitos porque se encontram inseridos em carreiras criminais (Machado e Porto, 2015). A prova de tal condição seria a prisão em flagrante, que dispensaria qualquer outro tipo de testemunho e perícia, já que o policial goza de fé pública em seu depoimento. Inclusive, a Súmula 70 do Tribunal de Justiça do Rio de Janeiro permite condenar por tráfico de drogas com base exclusivamente no depoimento dos policiais que atuaram no flagrante ${ }^{25}$, o que explicaria o reduzido tempo de processamento e o elevado número de condenações por esse crime na cidade do Rio de Janeiro (Lemgruber e Fernandes, 2015). Se as Varas de Tóxicos de Belo Horizonte reproduzirem a concepção do traficante como inimigo (Velho, 1998), tratando os flagrantes policiais como verdades absolutas (Jesus et al., 2011), a justiça em linha de montagem funcionará de maneira exemplar, ou seja, mais rapidamente.

Para testar essa hipótese, optamos por um modelo de regressão linear, em que a variável dependente é o tempo do processo (mensurado pela quantidade de dias transcorridos entre a distribuição e o encerramento) e as variáveis independentes são: (i) a presença do flagrante; (ii) o caso contar apenas com envolvidos do sexo masculino; e (iii) o envolvido contar com mais de um registro no banco de dados. Um modelo é, em verdade, uma aproximação da realidade, que pode ser conseguida a partir de uma equação matemática representada da seguinte forma:

Tempo de processamento $=\alpha+a X+b Z+c K$

O tempo de processamento é a dimensão que se pretende explicar e a quantidade de dias é distinta dependendo das variáveis independentes. Esse tipo de modelagem foi escolhido porque a variável resposta apresenta uma escala de mensuração contínua (variando entre 1 e 2.514 dias). As dimensões explicativas são denominadas variáveis independentes e inscritas na equação a partir de letras maiúsculas, sendo que $X$ representa

25 Súmula no 70. Processo penal. Prova oral. Testemunho exclusivamente policial. Validade. "O fato de restringir-se a prova oral a depoimentos de autoridades policiais e seus agentes não desautoriza a condenação". 
a presença de flagrante, $Z$, a presença de mais de um procedimento no nome do indivíduo e $K$, o processo que tem apenas envolvidos do sexo masculino.

O modelo estimado apresentou um $\mathrm{R}^{2}$ ajustado de 0,363 , o que significa dizer que a presença de flagrante, o processo ter acusados do sexo masculino (apenas) e o réu ter mais de um procedimento por tráfico de drogas no período analisado (2008-2015) explicam $36,30 \%$ da variação do tempo entre a data da distribuição e a data da baixa. Todas as variáveis foram estatisticamente significativas, mas a que impacta de maneira visível o tempo do processo é o flagrante (Tabela 2):

Tabela 2

Modelo de regressão linear que estima o tempo do processo a partir das seguintes variáveis: presença de flagrante, ser homem e contar com mais de um procedimento - Varas de Tóxicos de Belo Horizonte (jan./2008 e set./2015)

\begin{tabular}{|c|c|c|c|c|c|c|}
\hline & \multirow{2}{*}{ Modelo } & \multicolumn{2}{|c|}{$\begin{array}{c}\text { Coeficientes não } \\
\text { padronizados }\end{array}$} & \multirow{2}{*}{$\begin{array}{c}\begin{array}{c}\text { Coeficientes } \\
\text { padronizados }\end{array} \\
\text { Beta } \\
\end{array}$} & \multirow{2}{*}{$\mathbf{t}$} & \multirow{2}{*}{ Sig. } \\
\hline & & B & $\begin{array}{c}\text { Erro- } \\
\text { Padrão }\end{array}$ & & & \\
\hline & (Constante) & 621,267 & 6,647 & - & 93,463 & 000 \\
\hline & Flagrante & $-483,980$ & 4,716 &,- 561 & $-102,635$ &, 000 \\
\hline & Homens & $-15,742$ & 5,564 &,- 015 & $-2,829$ &, 005 \\
\hline & Caso duplicado & $-90,193$ & 4,017 &,- 123 & $-22,451$ &, 000 \\
\hline
\end{tabular}

Fonte: Elaboração própria com base em dados cedidos pelo Tribunal de Justiça de Minas Gerais.

Os coeficientes padronizados evidenciam que a variável que mais contribui para a diminuição do tempo de processamento é a presença do flagrante, ainda que ser homem e contar com um outro processo na Vara de Tóxicos também diminuam a quantidade de dias despendidos para a análise do crime. De acordo com os resultados dispostos na Tabela 2, o processo de um homem que já caiu nas malhas da justiça e que foi autuado em flagrante teria tão somente 31,37 dias de duração. Já os casos sem flagrante, com mulheres como autoras e sem qualquer passagem anterior pela justiça durariam 621,27 dias. Logo, a duração muito diminuta dos processos por tráfico de drogas, em comparação aos de homicídio, por exemplo, parece encontrar nos flagrantes a sua explicação.

Ribeiro e Duarte (2013, p. 30) encontram resultados semelhantes para a relação entre flagrante e tempo de processamento dos homicídios dolosos encerrados entre 2000 e 2007 na cidade do Rio de Janeiro. De acordo com as autoras, o flagrante representa uma extraordinária característica do funcionamento do sistema em linha de montagem: "se não é preciso coletar novas provas, o processamento do caso é mais ágil" (p. 30). Para elas, o fato de o flagrante reduzir de maneira drástica o tempo de processamento "corrobora a ideia de que o SJC é muito mais eficiente processando casos em que o conjunto probatório foi reunido no momento imediato de sua ocorrência do que casos nos quais a polícia deve realizar uma longa investigação para a reconstituição de provas" (p. 31). Além desse argumento, as autoras ressaltam a existência de outro fator, não menos admirável, qual seja, "o flagrante implica réu preso e, portanto, aceleração do processo" (p. 31), já que pessoas recolhidas ao cárcere têm prioridade no julgamento. 
Nos processos de tráfico de drogas, o flagrante impulsiona a meta da eficiência (Costa, 2015), fazendo com que todos os casos com a presença desse elemento sejam processados sem a coleta de novas provas e, provavelmente, resultem em condenações. Nesse sentido, o flagrante pode ser visto como a principal alavanca da justiça em linha de montagem, agilizando "sobremaneira o trabalho de diversos atores legais, maximizando a produtividade" (Sapori, 1995, p. 151), explicando por que as Varas de Tóxicos possuem um tempo de processamento muito inferior ao de outros processos penais. Afinal, a quantidade de flagrantes nessas instâncias é infinitamente maior e, com isso, a produção de provas termina dispensada (como dispõe a súmula 70 do TJRJ), decidindo-se o destino de quem é acusado da prática do tráfico de drogas somente com o depoimento do policial (Lemgruber e Fernandes, 2015).

As Varas de Tóxicos operam sob o paradigma da "justiça em linha de montagem" (Sapori, 1995) porque os procedimentos policiais classificados como "tráfico de drogas e condutas afins" são processados de maneira muito rápida, especialmente quando comparados com a morosidade característica do sistema de justiça criminal (Ribeiro et al., 2014). Aparentemente, nas Varas de Tóxicos da capital mineira, sob a máxima eficácia, reduz-se o tempo de processamento para quem já está nas malhas da justiça (Jesus et al., 2011); sob a máxima da eficiência, suprimem-se direitos e garantias fundamentais dos acusados como traficantes, já que o flagrante acelera substantivamente a velocidade do processamento (Lemgruber e Fernandes, 2015); sob a máxima da efetividade, aumentase ano após ano a quantidade de presos por tráfico de drogas no país (Azevedo e Cifali, 2015).

\section{Considerações finais}

Em seu artigo sobre administração da justiça penal, Azevedo argumenta que o grande ponto de inflexão na sociologia jurídica se operou na virada da década de 1960, sendo que "o marco inicial dessa tendência foi a utilização de técnicas e métodos de investigação empírica sobre a relação entre direito e sociedade, e a teorização que se seguiu sobre os resultados dessa investigação" (2014, p. 392). Neste artigo, foram utilizadas as formulações a respeito de como a justiça brasileira administra os casos de "tráfico de drogas e condutas afins" para análise da base de dados cedida pelo Tribunal de Justiça de Minas Gerais.

A primeira pergunta a que este artigo procura responder, a partir do uso de técnicas quantitativas de análise de dados, é sobre a participação percentual do delito de tráfico de drogas no total de procedimentos examinados pelo Tribunal de Justiça de Minas Gerais entre 2008 e 2015. Os estudos sobre a aplicação da Lei de Drogas indicam que existe uma tendência à negociação, por parte da polícia, dos casos de uso de drogas, sendo que o Judiciário seria acionado somente nos casos de tráfico de drogas (Grillo, Policarpo e Veríssimo, 2011). Os dados do TJMG parecem confirmar em parte essa tendência, posto que, ao longo do período analisado, a participação percentual de uso de drogas 
LUDMILA MENDONÇA LOPES RIBEIRO; RAFAEL LACERDA SILVEIRA ROCHA; VINÍCIUS ASSIS COUTO

praticamente desaparece, dando lugar à prevalência do tráfico de drogas. No entanto, como os casos de uso de drogas podem ser despenalizados por meio do sursis e suspensão condicional da pena no Jecrim e essas situações não foram computadas nesta análise, não é possível fazer uma afirmação mais conclusiva sobre o desenrolo nos casos envolvendo drogas.

A segunda pergunta dizia respeito aos fatores determinantes do tempo de processamento do tráfico de drogas nas varas de Belo Horizonte. A pesquisa sobre o assunto no Rio de Janeiro informa que esses processos tramitam de maneira substantivamente rápida, mas com a supressão das garantias do acusado, já que as prisões em flagrante podem ser utilizadas como fatores preponderantes da condenação (Lemgruber e Fernandes, 2015). Situação semelhante foi observada em São Paulo, localidade em que o tempo médio de processamento é de 142 dias (Jesus et al., 2011, p. 77). Os dados do TJMG confirmam essa tendência, já que os casos de tráfico de drogas são processados mais rapidamente que os de homicídio intencional (Ribeiro et al., 2014), sendo que o flagrante tem um peso determinante na equação, reduzindo em mais de $50 \%$ a quantidade de dias despendidos entre a distribuição e a baixa do processo. Porém, como o banco não possui dados detalhados sobre o padrão de decisão, limitando-se a dizer que o procedimento criminal se encerrou de maneira válida (com uma sentença que produz efeitos), os determinantes da condenação não puderam ser trabalhados.

A terceira pergunta se referia à possibilidade de enquadrar o processamento por tráfico de drogas em Belo Horizonte na categoria de "justiça em linha de montagem" (Sapori, 1995). Os dados disponíveis indicam que a maioria dos processos conta com homens na condição de autores do fato e que em um terço dos casos há mais de um registro, o que seria indicativo da carreira desviante, sem falar no peso do flagrante. Como as Varas de Tóxicos da capital trabalham com uma matéria-prima bastante homogênea, haveria uma tendência a tratar os casos da mesma forma, sem qualquer dimensão de individualidade. Os resultados obtidos indicaram que a homogeneidade - homens, com um procedimento enquadrado como tráfico e presos em flagrante - contribui para que o desfecho ocorra em menos de um mês após a distribuição do inquérito policial na justiça de Belo Horizonte. Aparentemente, estamos diante de uma "justiça em linha de montagem", que produz uma massa de encarcerados por esse delito (Azevedo e Cifali, 2015), sem qualquer possibilidade de questionamento diante do peso da palavra da autoridade policial responsável pelo flagrante (Lemgruber e Fernandes, 2015).

A análise de dados feita neste artigo indica que o formato do fluxo do tráfico de drogas não é um funil, com muitas ocorrências registradas na polícia e poucas processadas e punidas na justiça, mas um cilindro, já que quase tudo que entra no sistema de justiça criminal, especialmente por meio do flagrante, tende a ser processado e sentenciado rapidamente. Essa constatação aponta para o enorme poder que a ação policial tem em criar a distinção entre traficantes e usuários. Se o policial aplicar o rótulo de usuário a um determinado indivíduo, ele não será preso, mas convidado a comparecer ao Juizado Especial Criminal para recebimento de uma sanção despenalizadora, sendo que esse 
procedimento sequer será computado no banco de dados das Varas de Tóxicos (Campos, 2015). No entanto, se o policial interpretar a conduta como tráfico e rotular o indivíduo como traficante, ele será preso em flagrante e, provavelmente, irá aguardar o seu processo privado de liberdade. Uma vez nas Varas de Tóxicos, seu processamento será rápido, acelerado pelo flagrante e por outros elementos que indicam a carreira desviante do homem, como a presença de mais de um registro pelo mesmo crime no TJMG, fazendo desses locais exemplos privilegiados de como a "justiça em linha de montagem" funciona em nosso país.

Ludmila Mendonça Lopes Ribeiro - Professora do Departamento de Sociologia, pesquisadora do Centro de Estudos de Criminalidade e Segurança Pública, Universidade Federal de Minas Gerais. E-mail: <ludmila.ribeiro@gmail.com>.

Rafael Lacerda Silveira Rocha - Doutorando pelo Departamento de Sociologia, pesquisador do Centro de Estudos de Criminalidade e Segurança Pública, Universidade Federal de Minas Gerais. E-mail: <rochaunit02@gmail.com>.

Vinícius Assis Couto - Doutorando pelo Departamento de Sociologia, pesquisador do Centro de Estudos de Criminalidade e Segurança Pública, Universidade Federal de Minas Gerais.

E-mail: <viniccouto@gmail.com>

\section{Referências bibliográficas}

Adorno, S.; PASinato, W. "A justiça no tempo, o tempo da justiça". Tempo Social, vol. 19, n 2, p. 131-155, 2007.

Azevedo, R. G. Sociologia da administração da justiça penal. In: LimA, R.; RATton, J. L.; AzeVEdo, R. (orgs.). Crime, segurança e justiça no Brasil. São Paulo: Contexto, 2014.

AzeVedo, R. G.; Cifali, A. C. "Política criminal e encarceramento no Brasil nos governos Lula e Dilma: elementos para um balanço de uma experiência de governo pós-neoliberal". Civitas: Revista de Ciências Sociais, vol. 15, n 1, p. 105-127, 2015.

BAtitucci, E. C. "As limitações da contabilidade oficial de crimes no Brasil: o papel das instituições de pesquisa e estatística". São Paulo em Perspectiva, vol. 21, n 1, p. 7-18, 2007.

BeAto, C.; Zilli, L. F. "A estruturação de atividades criminosas: um estudo de caso". Revista Brasileira de Ciências Sociais, vol. 27, nº 80, p. 71-88, 2012.

BoIteuX, L. "A nova Lei Antidrogas e o aumento da pena do delito de tráfico de entorpecentes". Boletim IBCCRIM, São Paulo, vol. 14, n 167, p. 8-9, 2006.

BoIteux, L., et al. "Tráfico de drogas e Constituição". Relatório de pesquisa. Pensando o Direito, vol. 12, $\mathrm{n}^{\circ} 2$ 2, p. 2013. Brasília: Ministério da Justiça, 2009. Disponível em: <http://arquivos.informe.jor.br/clientes/justica/agencia/agosto/Sumario_executivo_pesquisa_Trafic o.pdf>. Acesso em: 10 jun. 2016. 
LUDMILA MENDONÇA LOPES RIBEIRO; RAFAEL LACERDA SILVEIRA ROCHA; VINÍCIUS ASSIS COUTO

BoITEuX, L. "Tráfico e Constituição: um estudo sobre a atuação da justiça criminal do Rio de Janeiro e de Brasília no crime de tráfico de drogas". Revista Jurídica da Presidência, vol. 11, n 94, p. 1-29, 2010.

CAmpos, M. S. "Pela metade: as principais implicações da Nova Lei de Drogas no sistema de justiça criminal em São Paulo", São Paulo. Tese de Doutorado. Universidade de São Paulo, 2015.

Coelho, E. C. "A criminalização da marginalidade e a marginalização da criminalidade". Revista de Administração Pública, vol. 12, n², p. 139-161, 1978.

CostA, A. T. M. "A (in)efetividade da justiça criminal brasileira: uma análise do fluxo de justiça dos homicídios no Distrito Federal". Civitas: Revista de Ciências Sociais, vol. 15, n 1, p. 11-26, 2015.

Grillo, C. C.; Policarpo, F.; Veríssimo, M. "A 'dura' e o 'desenrolo': efeitos práticos da Nova Lei de Drogas no Rio de Janeiro". Revista de Sociologia e Política, vol. 19, n 40, p. 135-148, 2011.

HELPES, S. S. "Vidas em jogo: um estudo sobre mulheres envolvidas com o tráfico de drogas", Juiz de Fora. Dissertação de Mestrado. Universidade Federal de Juiz de Fora, 2014.

Jesus, M. G., et al. "Prisão provisória e lei de drogas: um estudo sobre os flagrantes de tráfico de drogas na cidade de São Paulo". Relatório de pesquisa. Núcleo de Estudo da Violência da USP, São Paulo, 2011.

Kitsuse, J. I.; Cicourel, A. V. "A note on the uses of official statistics". Social Problems, vol. 11, $\mathrm{n}^{\circ} 2$, p. 131-139, 1963.

Lemgruber, J.; Fernandes, M. "Tráfico de drogas na cidade do Rio de Janeiro: prisão provisória e direito de defesa". Boletim CESeC, n 17, nov. 2015.

LimA, R. S.; Sinhoretto, J.; Bueno, S. "A gestão da vida e da segurança pública no Brasil". Sociedade e Estado, vol. 30, n 1, p. 123-144, 2015.

MACHADO, B. A.; ZACKSESKI, C.; RAUPP, R. M. "Tempos da investigação: o transcurso do inquérito policial no sistema de justiça federal". Revista Brasileira de Ciências Criminais, São Paulo, ano 24, vol. 124, p. 143-181, out. 2016 .

MAChAdo, B. A.; PORTO, M. S. G. "Homicídio na área metropolitana de Brasília: representações sociais dos delegados de polícia, promotores de justiça e magistrados". Sociologias, vol. 17, n 40, 2015.

MARINho, F. C., et al. A polícia judiciária no enfrentamento às drogas ilegais. Brasília: Secretaria Nacional de Segurança Pública (Senasp), 2014.

MingaRdi, G. Tiras, gansos e trutas: cotidiano e reforma na polícia civil. São Paulo: Scritta Editorial, 1992.

MISSE, M. "Malandros, marginais e vagabundos: a acumulação social da violência no Rio de Janeiro", Rio de Janeiro. Tese de Doutorado. Iuperj, 1999.

" "Crime, sujeito e sujeição criminal: aspectos de uma contribuição analítica sobre a categoria 'bandido'". Lua Nova, vol. 79, n 1, p. 15-38, 2010.

. Sujeição criminal. In: LimA, R. S.; RATTON, J. L.; AZEVEdo, R. G. (orgs.). Crime, polícia e justiça no Brasil. São Paulo: Contexto, vol. 1, p. 204-211, 2014.

NeUbACHER, F., et al. "Juvenile delinquency in central European cities: a comparison of registration and processing structures in the 1990s". European Journal on Criminal Policy and Research, vol. 7, $\mathrm{n}^{\circ} 4$, p. 539-562, 1999. 
NAS MALHAS DA JUSTIÇA: UMA ANÁLISE DOS DADOS OFICIAIS DE INDICIADOS POR DROGAS EM BELO HORIZONTE (2008-2015)

PAES, V. F. "Quem domina a regra do jogo: sobre a reforma da polícia e os registros policiais". In: MISSE, M. (org.). Acusados \& acusadores: estudos sobre ofensas, acusações e incriminações. Rio de Janeiro: Faperj/Revan, p. 165-186, 2008.

PAIXÃo, A. L. "A organização policial numa área metropolitana". Dados, vol. 25, n 1, p. 63-85, 1982.

RAmos, S.; MusumeCI, L. Elemento suspeito: abordagem policial e discriminação na cidade do Rio de Janeiro. Rio de Janeiro: Record, 2005.

Ribeiro, L.; DuARte, T. "O tempo dos Tribunais do Júri no Rio de Janeiro: os padrões de seleção e filtragem para homicídios dolosos julgados entre 2000 e 2007". Dilemas: Revista de Estudos de Conflito e Controle Social, vol. 2, n 3, p. 11-37, 2013.

Ribeiro, L.; MoARA, F.; CAmpos, Y. Fluxo e tempo do sistema de justiça criminal: uma análise dos casos de homicídios dolosos arquivados em Belo Horizonte (2003-2013). Belo Horizonte: Centro de Estudos de Criminalidade e Segurança Pública (Crisp), 2017.

RiBeiro, L. M. L., et al. Tempo médio do processo de homicídio doloso em cinco capitais. Brasília: Ministério da Justiça, 2014.

Rodrigues, T. Drogas, proibição e abolição das penas. Curso livre de abolicionismo penal. Rio de Janeiro: Revan, p. 131-151, 2004.

SAntoucY, L. B.; CONCEIÇão, M. I. G.; SudBraCK, M. F. O. "A compreensão dos operadores de direito do Distrito Federal sobre o usuário de drogas na vigência da nova lei". Psicologia: Reflexão e Crítica, vol. $26, \mathrm{n}^{\circ} 1$, p. 37-46, 2010.

SAPORI, L. F. "A administração da justiça criminal numa área metropolitana". Revista Brasileira de Ciências Sociais, vol. 10, n²9, p. 143-157, 1995.

Silva, K. A. "Tipologia dos homicídios: uma análise sociológica das denúncias oferecidas pelo Ministério Público de Minas Gerais". Revista Brasileira de Ciências Criminais, nº 74, p. 339-360, 2008.

VARgAS, J. D. Fluxo do sistema de justiça criminal. In: LimA, R. S.; Ratton, J. L.; Azevedo, R. G. (orgs.). Crime, polícia e justiça no Brasil. São Paulo: Contexto, vol. 1, p. 412-423, 2014.

VelHo, G. Desvio e divergência: uma crítica da patologia social. Rio de Janeiro: Zahar, 1974.

Duas categorias de acusação na cultura brasileira contemporânea. Sociedade e doença mental. São Paulo: Campus, p. 54-64, 1978. Vargas, 1998.

. Nobres \& Anjos: um estudo de tóxicos e hierarquia. Rio de Janeiro: Fundação Getulio

Veríssimo, M. "A Nova Lei de Drogas e seus dilemas: apontamentos para o estudo das formas de desigualdade presentes nos interstícios do ordenamento jurídico-penal brasileiro". Civitas: Revista de Ciências Sociais, vol. 10, n², p. 330-344, 2010.

Zaluar, A. A máquina e a revolta. São Paulo: Brasiliense, 1985. 


\section{Resumo}

Nas malhas da justiça: uma análise dos dados oficiais de indiciados por drogas em Belo Horizonte (2008-2015)

Neste artigo procuramos compreender como as Varas Criminais de Tóxicos da cidade de Belo Horizonte aplicam a Lei de Drogas (Lei 11.343/2006). Levando em conta as reconhecidas limitações inerentes aos registros oficiais, nosso objetivo é problematizar os limites e as possibilidades de entendimento do que ocorre com o indivíduo uma vez nas malhas da justiça a partir do banco de dados cedido pelo Tribunal de Justiça de Minas Gerais, referente a todos os procedimentos enquadrados na Lei de Drogas e encerrados na capital, entre janeiro de 2008 e setembro de 2015. Argumentamos que as Varas de Tóxicos funcionam como justiça em linha de montagem, especialmente, nos casos iniciados por flagrante, ainda que isso signifique supressão de direitos do acusado.

Palavras chaves: dados oficiais; Lei de Drogas; justiça em linha de montagem; flagrante

\section{Abstract}

In the judicial network: an analysis of official data for drug indictments in Belo Horizonte (2008-2015)

In this paper we intend to understand how the criminal courts in the city of Belo Horizonte apply the Drug Law (Law No. 11.343 / 2006). Taking into account the recognized limitations inherent to official records, our goal is to discuss the limits to and possibilities of understanding what happens to the suspects once they are in the judicial network, using the database of the Minas Gerais Court, which encompasses all procedures related to the Drug Law that were finalized in the capital between January 2008 and September 2015. We argue that courts specialized in drug crimes behave as a judicial assembly line, especially in cases in which the suspect has been caught red-handed, even if it means suppression of the defendant's rights.

Keywords: official records; Drug Law; assembly line justice; caught red-handed

\section{Resumen}

En las redes de la justicia: un análisis de los datos oficiales de indiciados por drogas en Belo Horizonte (2008-2015)

En este artículo se pretende comprender cómo los Juzgados Criminales de Tóxicos de la ciudad de Belo Horizonte (capital del estado de Minas Gerais, Brasil) aplican la Ley de Drogas (Ley 11.343/2006). Dadas las reconocidas limitaciones inherentes a los registros oficiales, nuestro objetivo es problematizar los alcances y las posibilidades de entendimiento de lo que ocurre con un individuo, una vez que se ve obligado a comparecer ante la justicia. La fuente principal de información empleada en el análisis es el banco de datos facilitado por el Tribunal de Justicia de Minas Gerais. Este contiene todos los procedimientos llevados a cabo dentro de la Ley de Drogas, y que fueron concluidos en la mencionada ciudad, entre el mes de enero del año 2008 y el mes de septiembre del año 2015. Se argumenta que en los Juzgados de Tóxicos se administra justicia al estilo de una línea de montaje, en particular, en los casos abiertos a partir de un flagrante, a pesar de que eso represente una supresión de los derechos del acusado.

Palabras-claves: datos oficiales; Ley de Drogas; justicia en línea de montaje; flagrante

\section{Résumé}

Dans les mailles de la justice: une analyse des données officielles des inculpés pour crimes liés à la drogue à Belo Horizonte (2008-2015)

Dans cet article nous cherchons à comprendre comment les Cours Criminelles de Belo Horizonte (capitale de I'état de Minas Gerais) appliquent la Loi sur les Drogues (Loi 11.343 du 23 août 2006). 
NAS MALHAS DA JUSTIÇA: UMA ANÁLISE DOS DADOS OFICIAIS DE INDICIADOS POR DROGAS EM BELO HORIZONTE (2008-2015)

Considérant que les limitations sont reconnues et inhérentes aux registres officiels, cette étude a pour but de problématiser les limites et les possibilités de compréhension de ce qui se passe avec l'individu pris dans les mailles de la justice, en se basant sur la banque de données remises par le Tribunal de Justice de Minas Gerais, au sujet de toutes les procédures se rapportant à la Loi sur les Drogues et qui se sont conclues à Belo Horizonte entre janvier 2008 et septembre 2015. Nous argumentons que les Cours Criminelles fonctionnent comme une justice sur une ligne de montage, spécialement dans les cas où il y a flagrant délit, bien que cela signifie la suppression des droits de l'accusé.

Mots-clés: données officielles; Loi sur les Drogues; justice sur une ligne de montage; flagrant délit

Artigo submetido à publicação em 17 de agosto de 2016. Versão final aprovada em 29 de junho de 2017. 